\title{
Designing Frequent Flyer Programs Effectively - a Market-Research- and Interview-Based Study for the German Aviation Sector
}

\author{
Mark Wever ${ }^{1}$ \\ ${ }^{1}$ University of Latvia, Riga, Latvia \\ Correspondence: Mark Wever, University of Latvia, Riga, Latvia.E-mail: mark.wever@gmx.de
}

Received: January 11, 2021

Accepted: January 26, 2021

Online Published: February 5, 2021

doi:10.5539/ijbm.v16n3p58

URL: https://doi.org/10.5539/ijbm.v16n3p58

\begin{abstract}
In the face of growing competitive pressure and the dilemma of revenue-cuts due to the Corona lock-down airlines have to question their marketing activities. Frequent Flyer Programs (FFP) of German airlines have to date been an important element of customer relationship marketing in the brand-airlines segment, but recently have been cut back due to doubts on their profitability.

The study refers to a comprehensive review of empirical studies in FFP to classify design characteristics of international programs. Referring to this classification it analyses the design framework of Germany's predominant Frequent Flyer program (Miles \& More) in the form of a case study, and compares the approach to international standards. Five insider expert interviews are conducted to evaluate the effectiveness of the concept and derive development options to secure the sustainable effectiveness of the program in a changing aviation market.

The study finds some adaptations to Miles \& More indispensable to make the program future-proof. A comprehensive and convincing framework comprising status, monetary and service rewards is essential to ensure consumer attractiveness and continuity. The partner network has to be expanded globally to ensure the programs international attraction. Bonuses have to be amended to particularly address frequent and international flyers Considering this advice, Miles \& More can become an important building block in a post-Corona airline marketing setup.
\end{abstract}

Keywords: frequent flyer program, airline, aviation, customer relationship, marketing, loyalty, empirical, market research

\section{Introduction}

\subsection{Frequent Flyer Programs - a Remedy to Competitive Pressure in the Aviation Market?}

The European aviation industry is in an existential crisis. The Corona lock-down has brought significant restrictions to the airline sector: in March 2020, 80 to 100\% of global flights were cancelled and to date flight frequency has reached only about $50 \%$ of the pre-Corona period (Mazareanu, 2020). This development has brought airlines significant revenue slumps. Given the insecurity of many passengers concerning the risk of infections during flights, flight demand could remain at a low even after a loosening of governmental aviation restrictions (Nižetić, 2020, p. 10953).

The impact of Corona, however, is only the peak of the iceberg of a more profound and prolonged crisis in the European aviation sector: Due to the progressive deregulation of international flight markets and the decrease of fuel prices, rival low-cost carriers from around the globe have gained important market shares in Europe. Their coverage has risen from $9 \%$ in 2002 to $43 \%$ in 2017. Since 2015, several established European Airlines have filed for insolvency as a result of tumbling flight prices, while transportation and administration costs are increasing (Powley, 2017).

Established airlines increasingly depend on a relatively small community of frequently flying customers (about $15 \%$ of flight passenger), who rely on proven service and quality standards and keep loyal to brand airlines (IATA, 2017, p. 5). Frequent Flyer Programs (in the following: FFP) were established since the 1980s to engage this target group. They are designed as bonus system for repeat booking that offer free flight miles and additionally e.g. priority check-in, separate lounges or board service, suggesting a VIP status (Peacock, 2019). FFP are usually kept as separate profit centers by airlines and often include external partner companies, which 
equally award credits or pay out premia (Pandit, 2018, p. 2).

Customer loyalty programs are well accepted internationally. $25 \%$ of UK and even $52 \%$ of US flight passengers join them (Bitran, 2018; Statista, 2018). About $77 \%$ of loyalty program members are willing to pay a price premium to participate in the programs (Crowd Twist, 2018). By 2018, airlines globally sold top-up miles worth 14 billion USD to customers and partners. Unredeemed miles and miles bought in advance by international business partners, which will never be refunded, promise additional revenues (Pandit, 2018, p. 4).

Critics, however, doubt the effectiveness of FFP from an airlines' perspective: budget-passengers book huge mileage at discount prices and average fare, passengers pay per mile flown decreases from 0.62 USD at 250 miles to 0.14 USD at 2,000 miles (PWC, 2015, p. 8), which reduces cost recovery contributions significantly. Airlines counter this problem by rising barriers to mile redemption and switching assignment schemes even after mileage acquisition (Tripathi et al., 2018, p. 4) a strategy which unnerves airline customers and shatters rather than increases loyalty and customer trust (Saxon \& Spickenreuther, 2018).

In effect, the impact of FFP on customer loyalty and booking intention is ambiguous. Airlines question the continuity and design of their programs but ignore the expectable outcome at the level of passengers.

\subsection{Study Objective and Method}

This study supports the aviation industry in the definition and adjustment of Frequent Flyer Programs to customer requirements. It combines a comprehensive review of research in impacts of Frequent Flyer Program design on consumer behavior, market research and an empirical qualitative survey among experts in the field.

Although an extensive body of research in FFP is available, so far, no comprehensive understanding on design factors of FFP and their impact on consumer behavior has been gained. None of the available studies refers to the German market, although the Star Alliance Frequent Flyer Program Miles \& More is among the most important Europe-wide and the German aviation sector is in particular concerned by low-cost carrier competition, as the insolvency of the renowned aviation company Air Berlin in August 2017 illustrates (Eiselin, 2017).

Based on the key assumption that FFP design impacts consumer booking, loyalty and recommendation behavior in the Airline sector, a comprehensive review is conducted to differentiate this assumption. The assumptions are founded and detailed in the empirical section, to derive an action plan for the adjustment and redesign of Frequent flyer programs, specifically Miles \& More. Applying the strategy, Star Alliance and comparable airline alliance can improve the customer impact of their FFP in a targeted way and at moderate efforts. Academic research gains an understanding on essential structural elements of FFP and their consumer impact.

\subsection{Status of Academic Research in Frequent Flyer Programs}

FFP are instruments of marketing and as such designed to develop and satisfy consumer needs, support the sales of airline services and increase the profitability of airline business operation (Bidlingmeier, 1983, p. 13-14). Diverse levels of impact of FFP are discussed in empirical FFP research.

\subsection{Consumer Impacts of FFP}

FFP are designed to strengthen customers' brand consciousness by taking up airline brands in their promotional campaigns and establishing own brands including further service offers from FFP partners. FFP extend the reach of partnering brands and particularly strengthen airlines brand image (Gudmundsson et al., 2002, p. 409). Financial incentives in FFP schemes, VIP treatment and service rewards convince customers of the quality of the brand and contribute to the formation of a positive brand image in FFP customers' mind (DeKay et al., 2009, p. 7; Tanford, 2013, p. 285).

Positive brand image associations strengthen customers satisfaction and loyalty i.e. future booking intention as a survey among Australian FFP members proves (Park et al., 2006, p. 375). Customer satisfaction results from the perceived high relationship investments of airlines, which customers experience by monetary savings, service advantages, status and social benefits (Mimouni-Chaabane \& Volle, 2010. p. 2). FFP make customers return just to belong to a perceived elite (Orhun \& Guo, 2018, p. 1).

FFP have been found to encourage customer advocacy and customer lifetime value: Since FFP reward schemes are progressive and offer growing status levels for passengers' continuity and recommendation, switching barriers grow with every booked flight (Uncles, 2003, p. 12) and impending credit decay due to periods of non-usage encourages repeat bookings (Woisetschlager, 2008, p. 484). Satisfied by the superior services, passengers actively communicate their conviction of the airline brand and FFP status with friends and colleagues and perhaps share bonus points with them (Rapp, 2000. p. 317). Non-FFP members, observing members' priority status are likely to develop the desire to attain the same superior treatment and stay loyal to the airline to 
progress to VIP status (Zins, 2001, p. 269). Perceived fairness of FFP creates positive performance expectations among members, which results in recommendation behavior (Mathies \& Gudergan, 2016, p. 3).

Airlines relationship investments in customers significantly contribute to enhance relationship quality and a long-lasting trusting customer partnership (Mimouni-Chaabane \& Vole, 2010. p. 26). Perceived personal economic, emotional and social value attributes of FFP increase customers' loyalty towards the airline (Lin et al., 2016, p. 39). FFP have been found to contribute to airlines' economic success, since they push booking figures, returns per booking (Hossain et al., 2016, p. 361), (due to higher realized booking prices) and market shares (Orhun \& Guo, 2018, p. 19) - factors, which finally contribute to increased profitability (Vilkaite-Vaitonè \&Papšienè, 2016, p. 114).

\subsection{Design Elements of FFP}

Design elements bringing forth the described desirable image formation, loyalty and repeat booking behavior are discussed controversially, concerning their effects. Essentially, three design factors are considered relevant monetary incentives, service rewards and status rewards.

Monetary incentives comprise rebases and pricing benefits (e.g. free miles or free flights) offered on the basis of collected credit points, which usually are assigned per booked mile or currency unit. Monetary incentives are perceived attractive when a high number of redemption options are available and numerous partners contribute to high program reach (Yan \& Cui, 2016, p. 1). Monetary incentives and superior treatment induce the perception of economic, psychological and interaction value with customers (Kreis \& Mafael, 2014, p. 592). Monetary rewards enhance customer- airline relationship quality, but their acceptance and impact depend on consumers' overall satisfaction with airline brand and flights (Keh \& Lee, 2006, p. 133).

Service incentives concern additional services that FFP passengers can receive free from charge or only against credit points and, which differentiate FFP passengers from conventional travelers, e.g. priority luggage service, free cancellations, short term ticketing. Service awards differ in effectiveness depending on passenger and travel type (Whyte, 2003, p. 278; Chin, 2002, p. 74), overall passenger satisfaction and brand conviction (Mathies \& Gudergan, 2013, p. 37). Their impact depends on the design of monetary rewards (Mimouni-Chaabane \& Volle, 2010. p. 26). Only sustainable care for customer service contributes to establish customer lifetime value (Keh \& Lee, 2006, p. 128).

Status rewards refer to immaterial benefits, which are based on the classification or status of the passenger alone, not on rebates or additional services. FFP passengers cherish the feeling of superior status and the social community with a perceived elite in-group (Wang, 2014, p. 58). Status awards mediate the feeling of recognition and impression of having a special status, being distinguished or treated better, although the distinction from service awards is not always clear. Status awards have been found to justify price premiums (Gao et al., 2018, p. 11 ,) effectively encourage loyalty if VIP status is tied to very frequent bookings and clearly visible (Mimouni-Chaabane \& Volle, 2010. p. 26) and even compensate for airline quality deficits (Orhun \& Guo, 2018, p. 1). The effectiveness of status awards, however, depends on culture and passenger type: Among Chinese passengers perceived status is the most effective tool to enhance relationship quality, but equally contributes to (undesired) customer entitlement, which reduces relationship impact if customer expectancies are not met (Ma \& Li, 2018, p. 306; Colakoglu \& Artuger, 2013, p. 1).

\subsection{Findings and Further Research Requirements}

The review details the assumption that FFP support airline marketing ins several respects, Behavioral effects are diverse: FFP influence consumers' attitude and more globally airlines' image. FFP contribute to customer satisfaction. FFP can encourage customer loyalty, which takes shape in repeat booking behavior and peer recommendation. These observations result in a first assumption T1:

\section{T1: FFP impact customer satisfaction, booking behavior, loyalty and recommendation behavior.}

FFP effectiveness results from an interplay of their key design elements monetary incentives, service and status awards. Positive behavioral effects of all three factors have been found but the interaction of design elements and external conditions to effectiveness is obvious: culture, passenger and travel type are of relevance. A second thus is plausible:

T2: Beyond monetary, service and status rewards further moderating and controlling factors interact to bring forth the observed customer impact of FFP, i.e. satisfaction and loyalty.

However, the exact impact chain and impact conditions of FFP are not fully clear so far. A more comprehensive and in-depth analysis of the design of particular FFP in a particular cultural context is required to devise and 
combine FFP design elements in a targeted way.

\section{Method}

\subsection{Combined Case-Study Methodology}

The empirical section combines document analysis and an interview-based empirical study. Referring on the review-insight that FFP impact is culture and target-customer specific, a case study design is chosen, which focusses on the Miles \& More program of Star Alliance. To assess the present design of Miles \& More in comparison to other Frequent Flyer Programs its parameters are evaluated in the form of a market overview. In-depth interviews with five Miles \& More insiders are conducted to assess how the design elements impact customer behavior and to found and concretize the review-based assumptions empirically. Triangulating these results, a measurement plan is developed, how Star Alliance and comparable airline networks can make their Frequent Flyer Programs future proof.

\subsection{Design of Market Analysis}

The market analysis refers to public data on international FFP and compares these to 'Miles \& More', the only German and one of the major European airline loyalty-program. Methodologically, the market research is based on Mayring's (2015, p. 62-63) recommendations for qualitative content analysis. It uses a set of variables and dimensions to uniformly classify different data sources and extract relevant information systematically so that an academically founded comparison is realized. The document coding scheme refers to categories retrieved from the systematic review and comprises characteristics of FFP, which as detailed above, are monetary, service and status awards. Monetary incentives are classified quantitatively with regard to the amount of money to be spent to earn miles, maximum time intervals to mileage expiry and opportunities to redeem mileage. Limitations and special conditions are summarized. Altogether the major 21 international FFP are assessed and the major design elements are compared to Miles \& More to assess the performance of the program as compared to market standards and characterize its design elements in detail as compared to competition.

\subsection{Design of Interview Study}

To explore the impact of Miles \& More on consumer behavior a problem-centered and semi-structured interview-design is chosen. The semi-structured interview is particularly suitable for the analysis of diverse understandings of individuals at different levels and in different contexts, since semi-structured interviews invite participants to classify themselves as actors on the scene of the research object (Mayring, 2016, p. 70).

To reach comparability of results the interviewees are presented the same set of questions, which include 1) data concerning the participant, 2) an analysis of the perceived efficiency of different FFP-design parameters, 3) the expected and observed behavioral effects of FFP among airline customers and 4) perceived moderators and controls of FFP effectiveness at the airline and customer level. The interview participants' positions and responsibilities are summarized in table 1:

Table 1. Interview participants

\begin{tabular}{|c|c|c|}
\hline & Position & 'Responsibility \\
\hline $\mathrm{P} 1$ & Board member of Star Alliance & Information on Star Alliance airlines but no direct access to FFP data \\
\hline $\mathrm{P} 2$ & $\begin{array}{l}\text { Part time advisor for Airlines } \\
\text { former vice president commercial at Star } \\
\text { Alliance }\end{array}$ & $\begin{array}{l}\text { Strategy and commercial issues } \\
\text { FFP information from earlier VP position }\end{array}$ \\
\hline P3 & $\begin{array}{l}\text { Advisor in Airline Business } \\
\text { Lecturer at International University at Bad } \\
\text { Honnef, Germany. }\end{array}$ & $\begin{array}{l}\text { Strategy consultation } \\
\text { Lectures on loyalty sales and E-Commerce }\end{array}$ \\
\hline P4 & $\begin{array}{l}\text { Professor at University of St. Gallen } \\
\text { Marketing }\end{array}$ & $\begin{array}{l}\text { Research in strategic marketing and CRM programs } \\
\text { Referent for Swiss Air formerly }\end{array}$ \\
\hline P5 & $\begin{array}{l}\text { Leader of airline competence center at } \\
\text { University of St. Gallen }\end{array}$ & Major research issue: loyalty and formerly loyalty programs \\
\hline
\end{tabular}

This selection of interview partners is balanced between a professional practice and academic context. Three participants are still involved in Star Alliance, and accordingly insiders concerning FFP in the German aviation sector, two use their earlier experience in this field in an academic context today. The participants cover different and complimentary qualifications in airline management and marketing. The selection of interview participants 
accordingly is representative with regard to the issue of the impact of Miles \& More on consumer behavior. The interviews were conducted on phone and interviewee were informed on the voluntariness of their participation and information. Interviewees double checked the transcribed interview text before further academic analysis.

The interview evaluation follows Mayring's standards for content analysis. The analysis progresses by research question and their structure is directly linked to the course of argumentation in the thesis, i.e. progresses from FFP design to FFP customer impact and potential moderators or controls of this relationship. Subcategories of analysis are formed if interviewees introduce new aspects, which are relevant to the core issue. Units of analysis comprise coding units, content units and evaluation units (Mayring, 2015, p. 51). Here full main clauses and full subclauses are chosen as minimal units of analysis (coding units), to stick to the intended sense of statements. Maximal content units extend to the comprehensive answer to a single question.

The research results are valid since the survey is based on categories gained from a comprehensive review of earlier empirical research. The results are reliable - in so far as possible for qualitative research - since the information originates from a representative sample of experts in the field of Miles \& More (Cooper \& Schindler, 2008, p. 244-247) and the interviews are evaluated according to a proven academic concept (Mayring, 2015, p. 58f). Potential biases result due to researcher's interpretation of interview texts and participants' readiness to disclose relevant information.

The interview and market research results are triangulated considering the review-based insights to develop recommendations to adjust the Miles \& More incentive scheme to optimize consumer impact.

\section{Empirical Results}

The empirical results comprise market-analytical and interview-based insights:

\subsection{Results of Market Analysis}

Today there are more than $220 \mathrm{FFP}$ worldwide, the most important 21 programs are assessed. Since enrollment is usually for free or inexpensive, most frequent travelers are members in several FFP (Global Flight, 2019, online). Table A2 (appendix) summarizes the collected data, which were retrieved form FFP websites and overview websites (Globalflight.net; J.D. Power; Bortz; Peacock; Finder) in summer 2019, the results inform on options for earning and redeeming miles, miles expiry and service-status awards, which are usually inseparable. The following analysis classifies the Miles \& More program, in the FFP market according to these criteria.

\section{Earning miles}

Airlines provide different schemes for earning miles in the process of booking flights. For all but one airline the assignment depends on the customer's status level attained in the program, which usually is calculated as a factor on the mile allocation in the lowest frequently flyer level. The column "earning miles" indicates a span of credit assignments for passengers depending on their status, $5-10 \mathrm{~m} / \$$ indicates that passengers in the lowest status rank obtain 5 miles per USD spent, while those in the highest rank obtain 10 miles for the same expense. Miles \& More disposes of a differentiate earning scheme for different partners.

In Europe and the USA, the assignment of credit points is the most common assignment scheme. Miles \& More adds a factor classifying the participating airline into this calculation. Asian Airlines use a booking-class and flight-category-based mile (or point) allocation scheme usually. Few airlines, connected to both Asian and Anglo-Saxon culture, use a mixed model and assign miles or credit points according to money spent and flight type: Air Canada allows customers to choose either system. Cathay Pacific calculates club points by adding up miles flown and price category. Alaska Air Group calculates the miles per flight class and fare class.

\section{Expiry}

Column "Expiry" indicates the number of months the miles stay valid when no further flight is booked. All but two airlines (Alaska Air Group and Japan Airlines) use expiry periods. European and US airlines use expiry periods of 18 to 24 months usually. Miles \& More grants 36 months. Most Asian providers or providers frequenting Asia use longer expiration periods e.g. 36 -120 months. Some, particularly Asian airlines make exemptions to expiration periods, which are indicated in column "limitations \& spec. conditions".

\section{Mile redemption and partner network}

Most airlines operate within a network of airline partners, which equally refund the miles gathered with the emitting airline. Only few airlines impose restrictions e.g. non-redemption days.

Virtually all FFP cooperate with travel-related external partner companies, particularly hotels and rent-a-car companies. Network sizes differ strongly. The largest FFP disposes of more than 1,000 external partners. The 
Miles \& More network comprises 27 companies, which share diverse Frequent Flyer Programs and is valid in more than 20 countries. The Miles \& More redemption scheme is complex, varies across partners and sets minimum mileage limits, from which redemption is possible and depending on the award zone. Most FFP, among them Miles \& More offer credit cards by the airline itself or an airline partner company. All airlines using credit cards in their FFP equally cooperate with shops, physical or/and online, which grant reductions on purchase prices as a refund for miles or credit points. Several airlines offer additional non-air-based services e.g. vacations, cruises, events, to FFP customers directly on their website, Miles \& More do not follow this promotion scheme.

Some airlines allow to transfer credit points or miles accrued with their company to other persons or institutions: Japan Airlines and Turkish Airlines offers family member credits or pooling, which allow other members of the family, up to a certain degree of relationship to participate in the bonus system when booking flights. Lufthansa Miles \& More, Air Canada and American Airlines allow customers to donate their credits for environmental causes $\left(\mathrm{CO}_{2}\right.$ tax) or listed organizations, but do not allow personal transference.

\section{Service \& Status awards}

Status rewards are homogenous in type across airlines. The following chart classifies benefits by flight state and comprises offers provided by most examined airlines to elite FFP members:

Table 2. Status \& Service awards

\begin{tabular}{lcll}
\hline \multicolumn{2}{l}{ Classification of status \& service awards } \\
\hline Booking Services & - & Simplified booking; Priority booking; Seat selection; Priority on waiting list \\
Airport services & - & Priority or economy check in; Lounge access; Press reader \\
Luggage services & - & Priority luggage transfer; Extra luggage; Heavier luggage allowed \\
Flight services & - & Priority boarding; Cabin class upgrade; Comfort seat; Upgrade on meal and drink \\
Partner services & - & Elite status in hotels and Elite status in rent-a-car companies \\
Promotions & - & Additional flight promotions; Premia and gifts of partners \\
\hline
\end{tabular}

All airlines differentiate among elite passengers and dispose of at least three of four elite member scales e.g. from bronze to platinum grade. The restrictions to reach elite member status and the respective levels differ.

There is no airline, which assigns status rewards after a certain period of membership or a certain total amount of acquired miles. Rather status awards usually have to be regained annually by booking new flights and are assigned for the recently accomplished booking period. Most airlines and all Western companies among them Miles \& More, tie access to elite status directly to their mileage point system and allow passengers access from a certain level. Access conditions to Mile \& More VIP status positions are not directly disclosed on the website but available from secondary pages only and maintenance of the (lowest) FF-status is limited to a number of 30 annual flights and 30,000 status miles (Luxury Travel Expert, 2019). Miles \& More terms and conditions are general and make no definite commitments on the height of miles accumulated by value of purchased good or service and neither on the value of miles or redemption (Miles \& More, 2019, online). Some airlines have got additional or substitute conditions to attain elite member status, which are even less transparent.

\subsection{Interview Results}

Interview results concretize and criticize the design and positioning of Miles \& More and provide suggestions to improve the system:

\section{Status and effectiveness of FFP design elements}

Interviewees critically appraise the changing design and diminishing attractiveness of Miles \& More incentives. it has contributed to a loss of attraction from a customer perspective: While twenty years ago airlines intended to maximize the booking quotas of their aircrafts, today customers struggle to obtain seats at all (P1). Today VIP seats are frequently not available. Miles \& More has further changed their FFP from miles- based to value-based incentive system, i.e. today, miles are granted only when price premia as compared to budget flights are paid (P1 \& P2). Due to restrictions on redemption, price rebates have lost in attraction according to P2 and P4 and travelers focus on status and service awards increasingly. Lounge access, fast tracks and extra bags are of interest to the major target group of status-oriented frequent business flyers. FFP incentives directed to "vanities" and image appeal a lot to business travelers. They do not mainly aim at collecting credits but at boasting with their personal advantages (P3). These special services are provided to inner circle members only, but these are ready 
to pay additional fees to maintain that status. For those status members, free flights are not of interest since they travel permanently anyway. They only want to keep their status and amenities, no matter at what price (P4). P5 adds that the cheaper privileged availability of consumer products on the basis of credit points has become a major attraction of Miles \& More recently.

\section{Development requirements for Miles \& More}

The interviewees' opinions on development requirements to ensure the survival of Miles \& More inform on, which development paths the incentive system could take in future: the transformation of the program from miles-based to value-based systems will continue according to P1, since flights are usually fully booked (or have been before the Corona-crisis). With the transition from miles to credits similar to an alternative currency, these credits have become taxable, which questions the whole miles concept and possibly the effect of FFP on consumer behavior could be lost, explains P5 and doubts that focusing on monetary awards is sustainable in future.

Airlines could, according to P1, expand their programs to further partners e.g. banks, which to date is only partly successful. Collecting miles is fascinating consumers, no matter, which mechanism is used. P4 explains that reach and number of FFP partners should be increased to ensure the competitiveness of Miles \& More. Bonus payments should be redeemable more easily if the FFP would be aligned with regular banks. To date the number of products and brands, FFP can be utilized for is limited. Coalition programs e.g with cinemas, filling stations and restaurants for instance could contribute to spread Miles \& More and to use it for the collection of consumer data (P2). P2 suggests that Miles \& More should refer to customer data from other providers more effectively to individualize promotional offers.

P4 disagrees: Miles \& More should turn its focus from consumer good marketing to service and status awards, since consumer goods are available cheaper through other intermediates meanwhile. Consumers are eager to collect status awards to represent their position in public. These awards however have to be limited to comparatively few passengers to maintain their effect and due to limited capacities (e.g. in lounges and on priority seats) (P1 \& P2).

\section{Moderators and controls of FFP effectiveness}

The participants see diverse moderators and controls to FFP effectiveness at the level of customers' habits and airline quality and safety: the attraction of mileage systems largely depends on the size and reach of the partner networks, which offers customers extensive options to utilize their miles. Miles \& More gains in effectiveness with reach and applicability. With the number of network participants, the range of offers increases, which attracts further members and increases the impact on customer loyalty. Far reaching networks enable partners worldwide to benefit of travelers (P1, 3, and 5).

P3 explains that FFP programs are only complimentary, while the major quality characteristics of airlines are punctuality, logistic convenience and pricing. According to P4, however, FFP are particularly effective when the reputation of the airline concerning the major quality criteria is not perfect. FFP can compensate travelers for other short comings. Discount carriers for instance can grant additional rebates through FFP, while for Swiss Airline, which enjoys an excellent reputation, FFP have hardly brought additional customers. Given the high quality of its airline partners, Miles \& More could thus prove little profitable.

The attraction of mileage systems according to participant 1 and 5, of course depends on customer and travel type. FFP are attractive to frequently flying business customers mainly. Private holiday flyers, on the other hand, are rather budget-oriented and utilize mileage systems to a much lower extent. Participant 4 agrees that the effectiveness of FFP largely depends on the customer, FFP should be designed for a special target market. P3 concretizes that FFP are effective when executives, who benefit from the bonus system do not have to pay for it, since their company is charged with the costs. Private travelers and self-employed business men do not enjoy mileage systems so much, since they are aware that it is them who pay for the benefits after all. According to participant 4, most companies have abolished personal benefits during flights anyway, which has reduced the attractiveness of such incentives.

The future of Miles \& More could be in addressing other cultures, e.g. Asia, where status is more important than in Europe. This potential could be limited however. Since customers book in their local markets most frequently, they usually benefit most of those FFP their local airlines offer. Miles \& More reaches the German market and German travelers mainly. 


\section{Discussion}

\subsection{Examination of Assumptions}

Triangulating the review results, market research and interview results, the assumptions derived from the review are re-examined.

According to T1, FFP impact customer satisfaction, booking behavior, loyalty and recommendation behavior. The interviews mainly confirm these assumptions, but interviewees are more critical on the development of FFP than academic literature. Customers are about to change their booking and loyalty behavior, due to growing budget carrier competition but equally due to changes in the Miles \& More reward system. Due to diminishing revenues by miles redemption barriers to bonus mils and discounts have been increased, which reduces the attractiveness of financial rewards to the majority of passengers. FFP members focus their engagement on discounts on consumer products and accordingly divert their interest from airlines to other members of the FFP system. The branding and attitudinal impact of Miles \& more is shrinking in result. Service \& status awards remain another principal aspiration of Miles \& More customers. The system however is not transparend concerning redemption options and places the mileage level to advance to VIP status increasingly high. This strategy puts the attraction of status \& service rewards at risk for the majority of customers, who will never acquire the required mileage limit per year. As soon as this strategy is noticed by a majority of customers, dissatisfaction with the system could undermine loyalty and recommendation behavior. The current development of the Miles \& More system accordingly questions the sustainability of the desirable customer impacts of FFP.

$\mathrm{T} 2$ postulates that beyond monetary, service and status rewards as well as further moderating and controlling factors interact to bring forth the observed customer impact of FFP. The interviews clearly confirm this proposition: the participants mention a range of customer, travel and airline-related moderating and controlling aspects: Customer culture and individual attitude determine openness to status and service awards. Particular customer groups, specifically frequently flying employees of larger corporations have got a positive incentive to utilize VIP programs, even if their companies incur extra costs for the required loyalty bookings. Miles \& More increasingly focusses its award system on very frequent and loyal flyers, while the majority of FFP members is gradually pushed out of the reward concept by obscure changes of the redemption system. FFP are found a complimentary concept strengthening airline attractiveness, while fundamental quality and security criteria are more important than bonus miles to the majority of passengers. Relying on FFP alone accordingly is no warranty for sustainable airline profitability.

\subsection{Strategy Plan for Miles \& More Development and Adjustment}

These results question the sustainability of the Miles \& More loyalty program in future. If the current development of stepping up barriers for mileage redemption with the airlines and the attainment of status awards is continued, the customer base of the Miles \& More system will dwindle, since the majority of passengers is excluded from drawing benefits of the system. Temporarily this is effect is not obvious, since Miles \& More membership is free from cost, and accordingly members have no incentive to phase out of the concept due to its unexpectedly low performance. In the long run, however, Miles \& More members will be disillusioned, if they recognize that their personal loyalty investment is not reimbursed as expected, but conditions are clandestinely changed to their disadvantage. Image losses and negative word of mouth will result, which could damage the reputation of airlines and Miles \& More partner companies. Changes to the current development of the Miles \& More system are necessary, accordingly, to ensure its future effectiveness.

The following strategic changes are suggested drawing on the results of interviews and market-research.

1. The attainability and continuity of monetary premia should be restored and reliably maintained, to reassure customers that their loyalty investment is not in vain but will truly be rewarded in future. Redemption conditions of Miles \& More should be simplified so that every passenger can understand them. They should be clearly published on the Miles \& More Website. Miles and more could use this image of seriosity to distinguish from competing international FFP.

2. Status awards have to remain limited to a narrow target group for capacity reasons and to maintain their impact. However, the transparency of communicating the levels to attain status rewards should be improved, by clearly stating access conditions on the Miles \& More webpage. This clarity would contribute to increase the credibility of the status in public and even heighten the image effect of the award system. Miles \& More should consider to expand the service award concept so that certain "entry awards", e.g. priority treatment at check-in or luggage services are made available from a lower mileage level onwards. Thus, the motivation for the majority of passengers to join the FFP would be increased in 
spite of higher transparency on access levels.

3. The interviews have shown that the target groups of Miles \& More are about to shift due to the deviation of holiday guests to budget carriers and due to a decaying status conscience among European and particularly German citizens, who so far are the main addressees of the program. The sustainable interest of executives in Miles \& More is threatened due to melting tax advantages in Europe. Miles \& More should thus switch its focal target groups: Asian citizens are more conscious of status advantages and possibly taxation of bonus systems is more relaxed outside of Europe. Non -European citizens could be reached more effectively by the Miles \& More concept, provided the marketing, promotion and availability of the program is extended to Asia.

4. To realize this objective of a shift and expansion of Miles \& More target customers, the alliance should significantly expand its partner network to Asian countries. In aviation partnerships with Asian airlines and FFP networks should be considered to ensure the continuity and transparency of reward systems from the perspective of Asian customers. A high number of system partners is crucial to Miles \& More's global competitiveness. High transparency standards and continuity of redemption conditions could contribute improve the attractiveness of Miles \& More as compared to Asian loyalty programs.

\subsection{Study Generalizability and Relevance}

The empirical section of this study has been realized as a case study for the major European and the only German FFP, Miles \& More. The market research has assessed Miles \& More characteristics as compared to 20 further major FFP. All five interviewees are involved with Miles \& More mainly. Still, the results basically trasferable to other FFP in Europe and internationally:

The market research has shown that the majority of FFP are complex and frequently obscure concerning mileage redemption and status \& service award availability. FFP could generally benefit of increasing the transparency of the system: Passenger trust in the concept would improve, which would attract members to a larger extent and equally heighten the image of the programs and member airlines.

Airlines world-wide face the competitive challenge by budget carriers and have to consider a change in the customer base of FFP. While previously holiday travelers benefitted of the concept, these increasingly enjoy more attractive conditions at budget carriers. Established airlines cannot compete on their prices due to higher service and administration costs. FFP cannot change this problem, but can increase the attractiveness of brand airline through the quality channel. They should explicitly be designed as superior quality concepts, which generally offer their members higher service levels and superior treatment against a price premium. In the opinion of the author the obscure strategy of redemption and status levels should be discarded, while FFP should explicitly be designed as payable service offers open to all passengers ready to pay for it. This quality distinction in an international member networks would improve established airlines reputation and competitiveness. In the situation of the Corona crisis this strategy is more topical than ever before, since passengers seek distance and security even for the sake of higher travel expenses.

\subsection{Limitations and Outlook}

Although the practice insights of this study are plausible and rooted in a profound multimethod analytical framework, some limitations and potential biases have to be considered: The range of literature in FFP and thus the category system of this study, which builds on a review of earlier research are limited. Further empirical research in FFP is necessary to develop a more stable theoretical basis for empirical analyses.

The market research presented here focusses on few aspects and due to limited transparency of FFP conditions, at least for non-members is not comprehensive. The classification of the Miles \& More system could thus be biased. Airlines are required to disclose more details in public to allow more profound research and provide consumers reliable orientation, when deciding for FFP membership.

Only five interviews with Miles \& More insiders have been conducted. This number is not statistically representative and the insights accordingly could be biased. A broader and quantitative data base is necessary to gain reliable insights. The main thesis, these results are extracted from, comprises a quantitative study, which fulfills these requirements. Still further empirical quantitative research beyond the Miles \& More Program is desirable to expand insights on FFP and develop practicable future strategies for aviation marketing.

\section{References}

Bidlingmeier, J. (1983). Marketing, Bd 1 (10th ed.). Opladen.

Bitran, M. (2018). How do American shoppers feel about brand loyalty? YoTPO Voice Blog. Retrieved from 
https://www.yotpo.com/blog/customer-loyalty-survey-data/

Chin, A. T. (2002). Impact of frequent flyer programs on the demand for air travel. Journal of Air Transportation, $7(2), 53-86$.

Crowd Twist (2018). Crowd Twist Consumer Loyalty Study Shows $87 \%$ of Gen Z Consumers Want Omni channel Loyalty Programs, PR Newswire. Petrieved from https://www.prnewswire.com/news-releases/crowdtwist-consumer-loyalty-study-shows-87-of-gen-z-consu mers-want-omnichannel-loyalty-programs-300729728.html

DeKay, F., Toh, R. S., \& Raven, P. (2009). Loyalty programs: Airlines outdo hotels. Cornell Hospitality Quarterly, 50(3), 371-382. https://doi.org/10.1177/1938965509338780

Eiselin, S. (2017). Von der Vorzeigeairline zum Krisenfall. Retrieved from https://www.aerotelegraph.com/so-wurde-air-berlin-gross

Colakoglu, O. E., \& Artuger, S. (2013). The Effect of Frequent Flyer Program on Customer Loyalty. The International of Social Sciences, 12(1), 33-43. https://doi.org/10.1016/j.jairtraman.2010.02.007

Davis, F. D. (1993). User acceptance of information technology/system characteristics, user perceptions and behavioral impacts. International Journal of Man-Machine Studies, 38(3), 475-487. https://doi.org/10.1006/imms.1993.1022

Cooper, D. R., \& Schindler, P. S. (2008). Business Research Methods. Singapore: McGraw-Hill.

Gao, Y., Carrigg, M., Lewinski, R., Polderman, D., \& Tkalcevic, P. (2018). The perceived value of frequent flyer program benefits among Australian travelers. International Journal of Aviation, Aeronautics, and Aerospace, 5(3), 6. https://doi.org/10.15394/ijaaa.2018.1249

Gudmundsson, S. V., de Boer, E. R., \& Lechner, C. (2002). Integrating frequent flyer programs in multilateral airline alliances. Journal of Air Transport Management, 8(6), 409-417. https://doi.org/10.1016/S0969-6997(02)00043-1

Hossain, M. Z., Kibria, H., \& Farhana, S. (2017). Do Customer Loyalty Programs Really Work in Airlines Business?-A Study on Air Berlin. Journal of Service Science and Management, 10(4), 360. https://doi.org/10.4236/JSSM.2017.104029

IATA. (2017). Airport Competition: Myth or Reality? Economic Briefing.

Keh, H. T., \& Lee, Y. H. (2006). Do reward programs build loyalty for services? The moderating effect of satisfaction on type and timing of rewards. Journal of retailing, 82(2), 127-136. https://doi.org/10.1016/j.jretai.2006.02.004

Kreis, H., \& Mafael, A. (2014). The influence of customer loyalty program design on the relationship between customer motives and value perception. Journal of Retailing and Consumer Services, 21(4), 590-600. https://doi.org/10.1016/j.jretconser.2014.04.006

Lin, Z., Quan, R., Lau, M. C. K., \& Ma, J. (2016). Customer perceived value of frequent flyer programs: An empirical study of airline passengers in China. In Handbook of Research on Consumerism and Buying Behavior in Developing Nations (pp. 30-52). IGI Global.

Ma, B., Li, X., \& Zhang, L. (2018). The effects of loyalty programs in services-a double-edged sword? Journal of Services Marketing, 32(3), 300-310.

Mathies, C., Gudergan, S. P., \& Wang, P. Z. (2013). The effects of customer-centric marketing and revenue management on travelers' choices. Journal of Travel Research, 52(4), 479-493. https://doi.org/10.1177\%2F0047287513478499

Mayring, P. (2015). Qualitative Inhaltsanalyse. Beltz: Weinheim.

Mayring, P. (2016): Einführung in die qualitative Sozialforschung. Eine Anleitung zum qualitativen Denken, Weinheim. Basel: Beltz Verlag.

Mazareanu. (2020). Weekly flights change of global airlines due to COVID-19. Retrieved from https://www.statista.com/statistics/1104036/novel-coronavirus-weekly-flights-change-airlines-region/

Mimouni-Chaabane, A., \& Volle, P. (2010). Perceived benefits of loyalty programs: Scale development and implications for relational strategies. Journal of Business Research, 63(1), 32-37. https://doi.org/10.1016/j.jbusres.2009.01.008 
Nižetić, S. (2020). Impact of coronavirus (COVID-19) pandemic on air transport mobility, energy, and environment: A case study. International Journal of Energy Research, 44(13), 10953-10961. https://doi.org/10.1002/er.5706

Orhun, A. Y., \& Guo, T. (2018). Reaching for Gold: Frequent-Flyer Status Incentives and Moral Hazard.

Pandit, P. (2015). Revitalizing Airline Loyalty - Frequent Flyer Programs. WNS Research Paper. Retrieved from: http://www.wns.com/Portals/0/Documents/Whitepapers/Revitalizing-Airline-Loyalty-Frequent-Flyer-Progr ams-Travel-and-Leisure.pdf?timestamp $=1449570172526$

Park, C. W., MacInnis, D. J., Priester, J., Eisingerich, A. B., \& Iacobucci, D. (2010). Brand attachment and brand attitude strength: Conceptual and empirical differentiation of two critical brand equity drivers. Journal of marketing, 74(6), 1-17. https://doi.org/10.1509\%2Fjmkg.74.6.1

Peacock, L. (2019). So What's the point? Business Travel. Retrieved from http://www.smarttravelasia.com/frequentflyer.htm

Powley, T. (2017). European airlines face more cuts and consolidation, Financial Times Germany. Retrieved from https://www.ft.com/content/b2b79a6e-a9f9-11e7-93c5-648314d2c72c

PWC (Price Water house coopers) (2016). Aviation perspectives The future of frequent flyer programs: Will you win or lose? PWC Transport \& Logistics, 3.

Rapp, R. (2000). Customer relationship marketing in the airline industry. In Relationship marketing (pp. 317-331). Springer, Berlin, Heidelberg.

Statista. (2019). Statistiken zum Durchschnittsgehalt in Deutschland. Retrieved from https://de.statista.com/themen/293/durchschnittseinkommen/\#: :text=3.770\%20Euro.,Arbeitnehmer\%20bet rug\%20monatlich\%201.890\%20Euro

Tanford, S. (2013). The impact of tier level on attitudinal and behavioral loyalty of hotel reward program members. International Journal of Hospitality Management, 34, 285-294. https://doi.org/10.1016/j.ijhm.2013.04.006

Tripathi, R. \& Gupta, N. \& Mazumder, S. (2018). Flying times for Airline Frequent Flyer Programs. Retrieved from https://www.infosys.com/industries/airlines/white-papers/Documents/airline-frequent-flyer-programs.pdf

Uncles, M. D., Dowling, G. R., \& Hammond, K. (2003). Customer loyalty and customer loyalty programs. Journal of consumer marketing, 20(4), 294-316.

Vilkaitė-Vaitonè, N., \& Papšienè, P. (2016). Influence of customer loyalty program on organizational performance: A case of airline industry. Inžineriné ekonomika, 109-116. https://doi.org/10.5755/j01.ee.27.1.10267

Wang, S. W. (2014). The moderating effects of involvement with respect to customer relationship management of the airline sector. Journal of Air Transport Management, 35, 57-63. https://doi.org/10.1016/j.jairtraman.2013.11.006

Whyte, R. (2003). Loyalty marketing and frequent flyer programmes: attitudes and attributes of corporate travellers. Journal of Vacation Marketing, 9(1), 17-34. https://doi.org/10.1177\%2F135676670200900102

Woisetschlaeger, D., Michaelis, M., \& Backhaus, C. (2008). The "dark side" of brand alliances: How the exit of alliance members affects consumer perceptions. ACR North American Advances.

Yan, W., \& Cui, Z. (2016). Factors contributing to popularity of loyalty programs: Evidence from emerging markets. Cornell Hospitality Quarterly, 57(2), 184-192. https://doi.org/10.1177\%2F1938965516636684

Zins, A. H. (2001). Relative attitudes and commitment in customer loyalty models: Some experiences in the commercial airline industry. International Journal of Service Industry Management, 12(3), 269-294. 


\section{Appendix A}

Overview on major Frequent Flyer Programs

Table A1. Characteristics of major international FFP (own analysis)

\begin{tabular}{|c|c|c|c|c|c|c|c|c|}
\hline No. & Airline & Country & Program & $\begin{array}{l}\text { Earning } \\
\text { miles }\end{array}$ & Expiry & Spending miles & Status rewards & $\begin{array}{l}\text { Limitations } \\
\text { Spec. } \\
\text { conditions }\end{array}$ \\
\hline 1 & Delta Airlines & USA & SkyMiles & $5-10 \mathrm{~m} / \$$ & 24 & $\begin{array}{l}\text { Flight booking with } \\
\text { Delta or partners } \\
\text { Sky Miles Credit } \\
\text { card } \\
\text { Sky Miles partners } \\
\text { Delta vacations and } \\
\text { cruises }\end{array}$ & $\begin{array}{l}\text { From } 20.000 \mathrm{~m} \\
\text { Elite status with } \\
\text { hotels and rent-a } \\
\text { car } \\
\text { Million miles } \\
\text { status }\end{array}$ & $\begin{array}{l}\text { Black-out } \\
\text { dates } \\
900 \quad \text { award } \\
\text { destinations }\end{array}$ \\
\hline 2 & $\begin{array}{l}\text { American } \\
\text { Airlines }\end{array}$ & USA & $\begin{array}{l}\text { AAdvantag } \\
\text { e }\end{array}$ & $5-11 \mathrm{~m} / \$$ & 18 & $\begin{array}{l}\text { Flight booking with } \\
\text { AA or partners } \\
\text { Saver or any-time } \\
\text { flight } \\
\text { Special prices } \\
>1,000 \text { partners } \\
\text { Donate to anybody }\end{array}$ & $\begin{array}{l}\text { Elite Status } \\
\text { Airport services } \\
\text { Upgraded } \\
\text { luggage terms } \\
\text { Lounge etc. }\end{array}$ & $\begin{array}{l}\text { Reactivation } \\
\text { fees }\end{array}$ \\
\hline 3 & $\begin{array}{l}\text { Deutsche } \\
\text { Lufthansa }\end{array}$ & Germany & $\begin{array}{l}\text { Miles \& } \\
\text { More }\end{array}$ & $\begin{array}{l}\mathrm{m} / € \\
\text { dependin } \\
\mathrm{g} \quad \text { on } \\
\text { partner } \\
\text { airline + } \\
\text { status }\end{array}$ & 24 & $\begin{array}{l}40 \text { Partners } \\
\text { Shopping } \\
\text { Hotels }\end{array}$ & $\begin{array}{l}35,000 \text { status } \\
\text { miles or } 30 \\
\text { flights required } \\
\text { Easier booking } \\
\text { Privilege status }\end{array}$ & $\begin{array}{l}\text { Mileage } \\
\text { bargains for } \\
\text { cheaper flights }\end{array}$ \\
\hline 4 & $\begin{array}{l}\text { United } \\
\text { Continental }\end{array}$ & USA & $\begin{array}{l}\text { Mileage } \\
\text { Plus }\end{array}$ & $5-11 \mathrm{~m} / \$$ & 18 & $\begin{array}{l}\text { Star Alliance \& } \\
\text { Mileage plus } \\
\text { Economy plus } \\
\text { purchases } \\
\text { Credit card }\end{array}$ & $\begin{array}{l}\text { Status premier } \\
\text { customer }\end{array}$ & $\begin{array}{l}\text { Limited } \\
\text { number of } \\
\text { seats for } \\
\text { awards }\end{array}$ \\
\hline 5 & $\begin{array}{l}\text { Air } \\
\text { France/KLM }\end{array}$ & France & Flying Blue & $4-8 \mathrm{~m} / €$ & 24 & $\begin{array}{l}\text { free luggage \& seats } \\
\text { shopping } \\
\text { hotels } \\
\text { experience points }\end{array}$ & $\begin{array}{l}25,000 \text { miles or } \\
15 \text { flights } \\
\text { Free lounges } \\
\text { from gold status }\end{array}$ & \\
\hline 7 & $\begin{array}{l}\text { South West } \\
\text { Airlines }\end{array}$ & USA & $\begin{array}{l}\text { Rapid } \\
\text { Rewards }\end{array}$ & $6-12 \mathrm{ct} / \$$ & 24 & $\begin{array}{l}\text { Flight and partners } \\
850 \text { online stores } \\
\text { Credit card }\end{array}$ & $\begin{array}{l}110.000 \mathrm{pt}= \\
\text { companion pass } \\
\text { (free flights for } \\
\text { partner) }\end{array}$ & \\
\hline No. & Airline & Country & Program & $\begin{array}{l}\text { Earning } \\
\text { miles }\end{array}$ & Expiry & Spending miles & Status rewards & $\begin{array}{l}\text { Limitations } \\
\text { Spec. } \\
\text { conditions }\end{array}$ \\
\hline 8 & $\begin{array}{l}\text { China } \\
\text { Southern } \\
\text { Airlines }\end{array}$ & China & $\begin{array}{l}\text { Sky pearl } \\
\text { club }\end{array}$ & $\begin{array}{l}\text { Fare } \\
\text { class \& } \\
\text { status }\end{array}$ & $\begin{array}{l}24 \text { (full) } \\
12 \text { (half) }\end{array}$ & $\begin{array}{l}\text { Flights with partners } \\
\text { Discount with Hertz } \\
\text { rent a car } \\
\text { Partner } \quad \text { with }\end{array}$ & $\begin{array}{l}\text { Advance seat } \\
\text { selection } \\
\text { Lounge service }\end{array}$ & \\
\hline 9 & $\begin{array}{l}\text { All Nippon } \\
\text { Airways }\end{array}$ & Japan & $\begin{array}{l}\text { ANA } \\
\text { Mileage } \\
\text { Club }\end{array}$ & $\begin{array}{l}\text { Flight } \\
\text { type \& } \\
\text { class }\end{array}$ & 36 & $\begin{array}{l}\text { American Airline } \\
\text { Flight awards/ } \\
\text { products } \\
\text { Hotel sty/ car rental }\end{array}$ & $\begin{array}{l}\text { Lounge, } \\
\text { concierge, } \\
\text { seat awards }\end{array}$ & \\
\hline 10 & $\begin{array}{l}\text { China Eastern } \\
\text { Airlines }\end{array}$ & China & $\begin{array}{l}\text { Dynasty } \\
\text { Flyer }\end{array}$ & $\begin{array}{l}\text { Booking } \\
\text { class, trip } \\
\text { weight, } \\
\text { accrual } \\
\text { ratio }\end{array}$ & 36 & $\begin{array}{l}\text { Flights with airline } \\
\text { Sky team partners }\end{array}$ & $\begin{array}{l}\text { Special senior } \\
\text { members } \\
\text { Priority check in, } \\
\text { guaranteed seats } \\
\text { free luggage }\end{array}$ & \\
\hline
\end{tabular}




\begin{tabular}{|c|c|c|c|c|c|c|c|c|}
\hline 11 & $\begin{array}{l}\text { Cathay Pacific } \\
\text { Airways }\end{array}$ & $\begin{array}{l}\text { Hong } \\
\text { Kong }\end{array}$ & $\begin{array}{l}\text { Marco Polo } \\
\text { Club }\end{array}$ & $\begin{array}{l}\text { Miles }+ \\
\text { Category } \\
= \\
\text { club } \\
\text { points }\end{array}$ & 12 & $\begin{array}{l}\text { Flight with } \mathrm{CP} \text { or } \\
\text { partners } \\
\text { Asia miles premia } \\
\text { Finance \& insurance } \\
\text { Telecom partners } \\
\text { Dining } \\
\text { Professional advice }\end{array}$ & $\begin{array}{l}\text { VIP lounge } \\
\text { Better seats } \\
\text { Economy check } \\
\text { in } \\
\text { Additional } \\
\text { luggage } \\
\text { Lounge access } \\
\text { Press reader }\end{array}$ & $\begin{array}{l}\text { Annual } \\
\text { renewal } \\
100-600 \\
\$ \text { turnover }\end{array}$ \\
\hline 12 & Air Canada & Canada & Aeroplan & $\begin{array}{l}\text { Choose } \\
\text { basis: } \\
\text { fixed } \\
\text { mileage } \\
\text { per flight } \\
\text { or market } \\
\text { price }\end{array}$ & 84 & $\begin{array}{l}\text { Flight with star } \\
\text { alliance } \\
\text { Purchase of products } \\
\text { Mile promotions } \\
\text { Credit Car } \\
\text { (Aeroplan \& } \\
\text { AMEX) } \\
\text { Environment } \\
\text { spending/ donation }\end{array}$ & & \\
\hline No. & Airline & Country & Program & $\begin{array}{l}\text { Earning } \\
\text { miles }\end{array}$ & Expiry & Spending miles & Status rewards & $\begin{array}{l}\text { Limitations } \\
\text { Spec. } \\
\text { conditions }\end{array}$ \\
\hline 13 & Japan Airlines & Japan & $\begin{array}{l}\text { JAL } \\
\text { Mileage } \\
\text { Bank }\end{array}$ & $\begin{array}{l}\text { Miles by } \\
\text { ticket } \\
\text { class, } \\
\text { fare, } \\
\text { flight } \\
\text { sector }\end{array}$ & - & $\begin{array}{l}\text { Flight with JAL \& } \\
21 \text { Partner airlines } \\
\text { Online shopping } \\
\text { Credit card } \\
\text { Premia exchange } \\
\text { Bus Tokyo shuttle } \\
\text { Family member } \\
\text { credits }\end{array}$ & $\begin{array}{l}\text { Fly on program: } \\
\text { travel benefits } \\
\text { from } 30.000 \mathrm{pt.:} \\
\text { reservation } \\
\text { desks, } \\
\text { lounge, } \\
\text { priority waitlist }\end{array}$ & $\begin{array}{l}1,000 \text { miles } \\
\text { registration fee } \\
\text { paid after pint } \\
\text { accumulation } \\
\text { Expiry on } \\
\text { withdrawal } \\
\text { from program }\end{array}$ \\
\hline 14 & $\begin{array}{l}\text { Turkish } \\
\text { Airlines }\end{array}$ & Turkey & $\begin{array}{l}\text { Miles \& } \\
\text { Smiles }\end{array}$ & $\begin{array}{l}\text { Dep on: } \\
\text { Class } \\
\text { continent }\end{array}$ & 36 & $\begin{array}{l}\text { Airline \& star } \\
\text { alliance members } \\
\text { premium tickets } \\
\text { Hotel } \\
\text { Car rental } \\
\text { Health care, training } \\
\text { Insurance } \\
\text { Shopping with miles } \\
\text { \& Smiles card } \\
\text { Family miles } \\
\text { pooling }\end{array}$ & $\begin{array}{l}25,000 \text { miles/ } 12 \\
\text { month } \\
\text { Premium tickets } \\
\text { Passenger } \\
\text { lounge } \\
\text { Free add. } \\
\text { luggage }\end{array}$ & $\begin{array}{l}\text { Extend } \\
\text { validity at } 10 \\
\mathrm{USD} / 1,000 \mathrm{~m}\end{array}$ \\
\hline 15 & $\begin{array}{l}\text { Qantas } \\
\text { Airways }\end{array}$ & Australia & Qantas FF & $\begin{array}{l}0.5 \mathrm{pt} . / \$ \\
\& \text { status } \\
\text { but } \\
\text { minimum } \\
\text { points } \\
\text { guarantee }\end{array}$ & 18 & $\begin{array}{l}8 \text { External airlines } \\
\text { Flights, hotels, car } \\
\text { hire } \\
\text { Shopping, dining } \\
\text { Phone, movies etc. } \\
\text { Several hundred } \\
\text { partners } \\
\text { Several credit cards }\end{array}$ & $\begin{array}{l}\text { Priority boarding } \\
\text { Qantas lounge }\end{array}$ & $\begin{array}{l}100 \$ \text { join up } \\
\text { fee }\end{array}$ \\
\hline 16 & $\begin{array}{l}\text { Singapore } \\
\text { Airlines }\end{array}$ & Singapore & Krisflyer & $\begin{array}{l}\text { Points by } \\
\text { class \& } \\
\text { tariff }\end{array}$ & 36 & $\begin{array}{l}\text { Flights with airline } \\
\& \text { partners } \\
130 \text { partner shops } \\
\text { Partner credit cards }\end{array}$ & $\begin{array}{l}\text { Club lounge } \\
\text { Premia }\end{array}$ & $\begin{array}{lr}\text { No own credit } \\
\text { cards } \\
\text { pay } \\
\mathrm{m} / 10.000 \\
\text { miles } \\
\text { extend }\end{array}$ \\
\hline No. & Airline & Country & Program & $\begin{array}{l}\text { Earning } \\
\text { miles }\end{array}$ & Expiry & Spending miles & Status rewards & $\begin{array}{l}\text { Limitations } \\
\text { Spec. }\end{array}$ \\
\hline
\end{tabular}




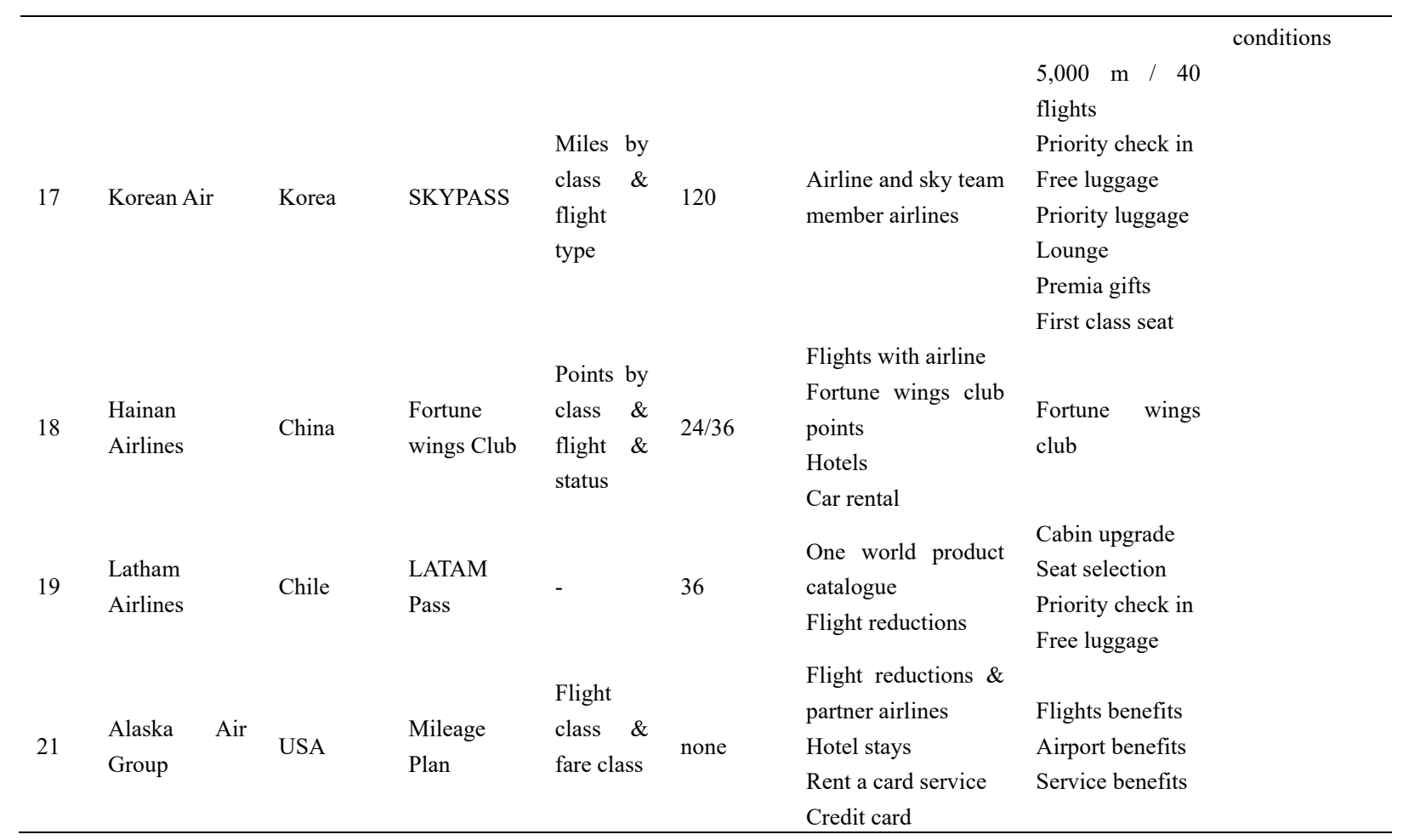

\section{Appendix B}

\section{Interview 1}

Name der Audio-/Videodatei: Interview P1 - Final cut

Dauer der Aufnahme: 00:06:31-0

Datum und Ort der Aufnahme: *durch Interviewer/in auszufüllen*

Besonderheiten: *durch Interviewer/in auszufüllen*

Datum der Transkription: 01.04.20

Ersttranskription: audiotranskription.de Transkriptionsservice

Überarbeitung(en), Datum: *durch Forschende/n auszufüllen*

I: Was ist Ihre derzeitige Position und in welchem Umfang beschäftigen Sie sich mit Kundenbindungsprogrammen in der Airline-Industrie? \#00:00:07-1\#

B: Ich war bis vor zwei, drei Jahren Mitglied der Geschäftsleitung der Star Alliance und habe da im Rahmen der Arbeit direkt, ja, Zugang zu den Informationen, die von den Star Alliance-Airlines mit uns geteilt wurde, gehabt. War aber nie direkt in der Verantwortung für Kundenbindungsprogramme. \#00:00:33-7\#

I: Hm. Welche Parameter von Frequent-Flyer-Programmen halten Sie für wirksam oder weniger wirksam und warum? \#00:00:42-8\#

B: Also dazu muss man, glaube ich, kurz ausholen, weil die Frequent-Flyer-Programme haben sich, seitdem sie geschaffen wurden, in den letzten Jahren doch erheblich auch verändert in ihrer Natur und Wirkungsweise. Das lag daran oder liegt daran, dass die Fluggesellschaften anders als noch vor zwanzig Jahren doch sehr stark damit beschäftigt waren, die Auslastung ihrer Flugzeuge nach oben zu treiben. Und dementsprechend WURDEN die Meilenprogramme weniger attraktiv dadurch, dass nämlich nur noch wenige Sitzplätze für Meilenprogramme überhaupt zur Verfügung standen. Zum anderen ist es so, dass die Preissituation in der Luftfahrt sich auch geändert hat und dementsprechend das rein meilenbasierte System von vielen Fluggesellschaften, insbesondere denen, die von dem Erfolg dieser Systeme weiterhin überzeugt sind, umgewandelt wurden in wertbasierte 
Systeme. Also weg von den entfernungsbasierten hin zu wertbasierten Systemen auf der einen Seite. Und was auch hinzu kam, kam dann die Einführung der sogenannten dynamischen Sitzplatzvergabe auf der anderen Seite, das heißt: wenn man denn noch einen Sitz ergattern möchte, dann muss man notfalls auch mehr Meilen dafür einsetzen, wenn es sich um einen hoch ausgelasteten Flug handelt. Dadurch ist aus Sicht der Konsumenten das System doch stark verändert worden und hat, wie man immer wieder auch gehört hat, ja zum Verlust an Attraktivität geführt. \#00:02:33-2\#

I: Hm, okay. Wie würden Sie Frequent-Flyer-Programme weiterentwickeln, damit sie effektiver werden und was würden Sie hoffen zu erreichen? \#00:02:43-4\#

B: Ja gut, also den Airlines, die das bisher noch nicht gemacht haben, wird wohl nichts anderes übrig bleiben/ Gut, jetzt mal abgesehen davon, wie wir erstmal sehen müssen, wie diese Krise sich entwickelt, aber aus/ Gehen wir mal davon aus, dass wir dieses Gespräch führen, als WÜRDE es noch viele Strecken und zu 90, 95 Prozent ausgelastete Flugzeuge geben. Dann ist an einen solchen Schritt hin zu wertbasierten Systemen und hin zu dynamischen Sitzvergaben/ führt kein Weg dran vorbei. Denn nur so kann man diese System auch in Zukunft/ oder konnte man sie bis vor vier Wochen auch in Zukunft nur sinnvoll managen. Viel ist versucht worden über die Ausweitung in der Zusammenarbeit mit Banken, mit anderen Kundenbindungssystemen. Meines Wissens oder nach meinen Beobachtungen sind diese Versuche aber eher an der Peripherie erfolgreich. Das aktive Meilensammeln ist nach wie vor aus Sicht des Kunden ein spannendes Thema und wird auch nach wie vor häufig genutzt. \#00:04:02-8\#

I: Hm. Sind Sie der Meinung, dass die Wirksamkeit von Frequent-Flyer-Programmen von weiteren Parametern abhängt? \#00:04:11-2\#

B: Können Sie mir dazu, zu der Frage, mal noch bisschen mehr Hintergrund geben, was Sie da sehen würden als weitere Parameter? Also auf Anhieb kann ich das so nicht bewerten, also weil/ Was Sie mit Parametern meinen. \#00:04:32-5\#

\section{I: Ja, Parameter könnten ja sein die Verfügbarkeit von, sagen wir, Meilentickets, Fast Track/ \#00:04:42-6\#}

B: Ja, also gut, wenn wir das/ Wenn wir also praktisch auf die Status-Thematik da angehen, das ist nach wie vor natürlich ein ganz wichtiger Parameter. Ich würde im Übrigen auch sagen, dass die Verwendung der angesammelten Meilen in einem größeren System, zum Beispiel im System der Allianzen, sich über die Jahre hinweg als sehr, sehr großer Benefit herausgestellt hat, auch für die Meilensysteme der unterschiedlichen Airlines. Also das heißt, in dem Maße, in dem man mehr Angebot zur Verfügung stellt, wächst auch die Attraktivität des Systems. Leider war es in den vergangene Jahren aber so, dass das eher umgekehrt dann passiert ist. \#00:05:28-0\#

I: Hm. Und letzte Frage: Glauben Sie, dass die Wirksamkeit von Frequent-Flyer-Programmen je nach Kundentyp, Reiseart und Fluggesellschaft unterschiedlich ist? Wenn ja: in welcher Hinsicht? \#00:05:40-8\#

B: Eindeutig ja. Also der Kunde, der nur ein-, zweimal im Jahr in Urlaub fliegt, der hat andere Parameter für seine Entscheidung, Kaufentscheidung, als der, der das Flugzeug als häufiges Reisemittel wählt. Auch der, der für seine eigenen Kosten nicht selber aufkommen muss, sondern der das Ticket vom Arbeitgeber bezahlt bekommt, ist leichter gewillt, dann auch seine Reiseentscheidung eher an solchen Systemen wie Frequent-Flyer-Programmen auszurichten, anstatt rein betriebswirtschaftlich zu denken. Auch diese Beobachtung gibt es seit Anbeginn der Systeme. Und hat auch zum Erfolg dieser Systeme beigetragen. \#00:06:28-2\#

I: Hm. Gut, vielen Dank. 
Interview 2: Representative of Miles \& More $\mathrm{GmbH}$

Name der Audio-/Videodatei: Interview P2 - Final cut

Dauer der Aufnahme: 00:06:38-7

Datum und Ort der Aufnahme: *durch Interviewer/in auszufüllen*

Besonderheiten: *durch Interviewer/in auszufüllen*

Datum der Transkription: 01.04.20

Ersttranskription: audiotranskription.de Transkriptionsservice

Überarbeitung(en), Datum: *durch Forschende/n auszufüllen*

I: Erste Frage: Was ist Ihre derzeitige Position und in welchem Umfang beschäftigen Sie sich mit Kundenbindungsprogrammen in der Airline-Industrie? \#00:00:07-4\#

B: Derzeit bin ich Teilzeit-Berater im Airline-Umfeld. Da mache ich alles, was Strategie- und Commercial-Dinge angeht. Aber meine Beziehung zu FFP-Programmen stammt aus meiner vorhergehenden Tätigkeit. Ich war auch wie P1 bei Star Alliance, dort als Vice President Commercial. Und hatte/ Also mein Portfolio wuchs immer und ich kriegt dann irgendwann auch Marketing und Loyalty hinzu, da war ich etwa, ich schätze mal, vier Jahre verantwortlich. Bis 2016. \#00:00:51-2\#

I: Hm, vielen Dank. Welche Parameter von Frequent-Flyer-Programme halten Sie für wirksam oder weniger wirksam und warum? \#00:00:58-8\#

B: Ja, das ist so eine Frage, die/ Ich habe Ihre Fragen schon mal durchgelesen, da kommt dann bei der letzten nochmal hinzu: Je nach Zielgruppe sind die unterschiedlich wirksam. Der Seltenflieger, sage ich mal/ Na, der Seltenflieger ist für Frequent-Flyer-Programme sowieso nicht interessant. Aber der, der nicht so häufig fliegt, der lässt sich vielleicht reizen von Punkten oder Meilen oder wie auch immer die Währung genannt wird, um eben einen Discount auf einen günstigen Flug einzuräumen oder einen Freiflug. Es gibt ja so ganz simple: Buy ten, get one free. Die gab es auch in der Airline-Branche mal ganz am Anfang von einzelnen Local Carriern. Also die Infrequently Flyers, die sind davon angesprochen. Aber die wirklich vielfliegenden in meiner Erfahrung sind viel mehr über die Status und Benefits loyal zu bekommen. Darf ich in die Lounge rein? Kriege ich einen Fast Track? Kriege ich eine Extrabag oder so. Das sind die Benefits, die wirklich ziehen bei DER Zielgruppe, die zumindest wir bei Star Alliance hauptsächlich im Blick hatten. \#00:02:22-1\#

I: Hm. Wie würden Sie die Frequent-Flyer-Programme weiterentwickeln, damit sie effektiver werden und was würden Sie hoffen zu erreichen? \#00:02:30-2\#

B: Ich glaube, das Potential, das in den Daten liegt, wird bei Weitem noch nicht ausgeschöpft. Google weiß ja viel mehr über Sie und über mich als die Lufthansa, sage ich mal. Und dabei könnten die Airlines einzeln und insbesondere in Kooperation zum Beispiel in so einer Allianz, für die ich tätig war, deutlich mehr Daten generieren und dann auch intelligent ausnutzen. So würde ich es weiterentwickeln. \#00:03:08-7\#

I: Hm. Sind Sie der Meinung, dass die Wirksamkeit von Frequent-Flyer-Programme von weiteren Parametern abhängt? \#00:03:15-4\#

B: Die habe ich nicht ganz verstanden, die Frage. Können Sie ein bisschen erläutern? \#00:03:22-2\# 
I: Ja, eventuell gibt es ja noch weitere Parameter, die jetzt über die genannten halt hinausgehen oder Benefits, die den Frequent Flyern offeriert werden, die, ja, auf die Wirksamkeit einzahlen? Oder sie/ Ja. \#00:03:40-3\#

B: Okay. Bleiben wir mal bei Airline-Frequent-Flyer-Programs. Es gibt gar nicht so viele Airline-Frequent-Flyer-Programs, die auch so einen Shop dranhängen haben, dass man seine Meilen also einsetzen kann für Smartphones oder sowas. Also davon gibt es NICHT so viele und die, die es gibt, die sind nicht besonders effektiv. Weil wenn man da einen Preisvergleich anstellt für das iPad, das halte ich auf dem freien Markt/ Häufig ist das gar nicht so attraktiv. Das wäre ein Parameter, wo man sich weiterentwickeln kann. Gibt auch, keine Ahnung, ich glaube, in UK (Neck da?) welche, die den Bereich des Flugs viel mehr verlassen, wo man eben seine Meilen dann auch aufstocken kann, indem ich tanke oder in der Apotheke kaufe oder ins Kino gehe. Also das sind, wie heißen die, Coalition Programs, die viel, viel, viel breiter gefasst sind. Und auch da, komme ich wieder zurück auf das, was ich vorher gesagt habe, kann ich Daten sammeln, die ich, wenn ich nur Airline bin und nur Airline-Transaktionen auswerte, gar nicht wissen könnte. \#00:04:59-7\#

I: Hm. Kommen wir schon zur letzten Frage: Glauben Sie, dass die Wirksamkeit von Frequent-Flyer-Programme je nach Kundentyp, Reiseart und Fluggesellschaft unterschiedlich ist? Wenn ja, in welcher Hinsicht? \#00:05:12-3\#

B: Ja, wie ich eingangs schon gesagt habe: Kundentyp, also DER Geschäftsreisende, der permanent die ganze Zeit im Flugzeug unterwegs ist, der will gar keinen Freiflug haben, der ist froh, wenn er mal zu Hause bleiben kann. Ganz anders der Tourist, der eben zweimal Langstrecke fliegt und dann Punkte gesammelt hat, die er für irgendwas einsetzen kann. Reiseart habe ich ja auch gerade angesprochen, Geschäftsreisen deutlich anders als Privatreisen, gibt es noch diese dritte Kategorie "VFR", Visiting Friends and Relatives, die sind nochmal ganz anders motiviert, aber eher wie Touristen zu betrachten in dem Zusammenhang. So, Fluggesellschaft ja. Da haben wir die Kategorien der Full Service Network Airlines und die andere große Kategorie Low Cost Airlines, die anfangs gar nicht sowas eingeführt haben. Und, ich glaube, Air Asia hat dann angefangen, auch ein Frequent-Flyer-Programm aufzusetzen. Auch DORT gibt es wiederkehrende Kunden, aber die sind in erster Linie, wenn man das so pauschal sagen kann, alle über den Preis getriggert und erst in zweiter Linie über irgendwelche Loyalty-Programme. \#00:06:33-0\#

I: Hm. Gut, alles klar. So viel zu den Fragen. Vielen Dank.

Interview 3

Name der Audio-/Videodatei: P3 - Final cut

Dauer der Aufnahme: 00:11:09-8

Datum und Ort der Aufnahme: *durch Interviewer/in auszufüllen*

Besonderheiten: *durch Interviewer/in auszufüllen*

Datum der Transkription: 01.04.20

Ersttranskription: audiotranskription.de Transkriptionsservice

Überarbeitung(en), Datum: *durch Forschende/n auszufüllen*

$---$

I: Was ist Ihre derzeitige Position und in welchem Umfang beschäftigen Sie sich mit Kundenbindungsprogrammen in der Airline-Industrie? \#00:00:06-2\#

B: Da muss ich zwei Teilantworten geben. Das eine ist, ich bin als Berater in der Luftfahrtbranche unterwegs. Insbesondere mit den Schwerpunkten Strategie und Prozesse und so weiter. Da gibt es natürlich eine ganze Menge Aspekte, die da Überschneidungen und Anknüpfpunkte zum Thema Kundenbindung haben. Und zum Zweiten bin ich im Moment auch tätig als Gastdozent an der IOBH und lese da unter anderem Sales und E-Commerce und auch da gibt es natürlich die Frequent-Flyer-Programme als einen wesentlichen Inhalt. 
\#00:01:00-5\#

I: Hm. Zur zweiten Frage: Welche Parameter von Frequent-Flyer-Programmen halten Sie für wirksam oder weniger wirksam und warum? \#00:01:10-3\#

B: Was definitiv sehr stark wirkt, ist das Element, was letztlich die Eitelkeiten anspricht. Sprich: Wenn man jetzt einen gewissen Status hat über gesammelte Statusmeilen, egal bei welcher Firma, also bei welcher Airline, bei welcher Allianz, das ist was, wo die Geschäftsreisenden schon ganz gerne mit kokettieren nach meiner Beobachtung. Was die/ wie soll ich sagen, den eigentlichen Ansatz angeht, also Kunden dazu zu bringen, möglichst eine Airline zu benutzen, das sieht schon ein bisschen kritischer aus, weil da gibt es durchaus den Effekt, wenn die Leute für eine Firma unterwegs sind, sprich: Die Firma zahlt, der Karteninhaber sammelt aber die Meilen für sich persönlich, da funktioniert es auch ganz gut. Weil die Benefits letztendlich dann nachher bei dem Reisenden liegen. Wenn aber das Zahlen für eine Reise mit der Entscheidung, wen nutze ich, unmittelbar zusammenfällt, dann wird die Kundenbindung nicht mehr so gut, weil dann zählt doch letztendlich unterm Strich: Was kostet ein Ticket? Und wie viel kostet es bei Wettbewerbern und da sind also die, wie soll ich sagen, ist die Sogwirkung eines Sammeln von Meilens nicht mehr ganz so groß. Also gerade so diese kleinen quasi inhabergeführten Geschäfte, wenn der Inhaber dann selber fliegt, dann/ Und das geht sowieso in die gleiche Kasse rein, dann trifft er seine Entscheidungen nach Preislage. \#00:03:15-7\#

I: Hm. Okay, vielen Dank. Wie würden Sie Frequent-Flyer-Programme weiterentwickeln, damit sie effektiver werden und was würden Sie hoffen zu erreichen? \#00:03:24-7\#

B: Also ich glaube, ehrlich gesagt, dass die Weiterentwicklung im Bereich der Airlines eher schwierig sein wird, denn letztendlich verkaufen wir da ein Produkt, das zum einen ein bisschen ähnlich ist wie Waschmittel. Also alle erzählen, dass es ganz unterschiedlich/ also Riesenunterschiede gibt. De facto geht es um den Transport von A nach B und die Qualitätsparameter, die sind in der Regel solche wie: Passt der Flugplan? Ist die entsprechende Leistung, der Transport, dann auch pünktlich und zuverlässig und werde letztendlich nicht nur ICH dann pünktlich da sein, sondern mein Gepäck auch? Und da ist der Unterschied zwischen den Airlines de facto relativ gering, sodass die Frequent-Flyer-Programme in der Regel auch, wie soll ich sagen, im Wettbewerb unter den Airlines zwar immer wieder als starkes Wettbewerbselement verkündet werden, de facto funktionieren sie aber vor allen Dingen im Heimatmarkt einer Airline sehr, sehr gut, um da die Bankposition gegenüber den anderen noch, den Wettbewerbern außerhalb des Heimatmarktes dann massiv Anteile abzunehmen, aber das gleicht sich dann über die, wie soll ich sagen, so über den Gesamtwettbewerb aus. Also in Deutschland funktioniert Miles and More sehr stark für Lufthansa. Mit Miles and More in Frankreich wird es allerdings schon deutlich schwieriger. Da ist es eher so, dass eben in Frankreich dann eben das Kundenbindungsprogramm der Air France überproportional wirkt. Und das von Lufthansa und British Airways und wer da sonst noch so unterwegs ist, eben eher unterproportional. \#00:05:28-2\#

I: Hm. Okay. Sind Sie der Meinung, dass die Wirksamkeit von Frequent-Flyer-Programmen von weiteren Parametern abhängt? \#00:05:36-7\#

B: Ja, letztendlich muss man sagen, die anderen/ Also ich habe ja vorhin schon genannt: Pünktlichkeit, Regelmäßigkeit, passt der Flugplan, ist der Preis einigermaßen erträglich für Geschäftsreisende, das sind eigentlich die Faktoren, die die Basis legen. Und dann wird das Meilensammeln quasi noch als Benefit oben drauf gesehen, also das Kundenbindungsprogramm ist sicherlich nicht das primär Ausschlaggebende für die Kaufentscheidung. \#00:06:12-9\#

I: Hm. Und letzte Frage: Glauben Sie, dass die Wirksamkeit von Frequent-Flyer-Programmen je nach Kundentyp, Reiseart und Fluggesellschaft unterschiedlich ist? Wenn ja in welcher Hinsicht? \#00:06:25-6\#

B: Ja, das ist definitiv unterschiedlich und da gibt es ganz, ganz viele Aspekte, die man betrachten kann. Also das 
eine ist sicherlich das, was ich vorhin schon gesagt habe. Kundenbindungsprogramme wirken im Heimatmarkt einer Airline ganz massiv FÜR sie und in anderen Märkten muss man dann aber mit unterproportionalen Effekten rechnen. Letztendlich ist DAS zurückzuführen ja auf die Frage oder, sagen wir mal, auf den Ansatz, dass es für einen Kunden gar nicht so sehr entscheidend ist, wie viele Meilen bekomme ich denn pro Flug. Sondern wenn ich Kunde bin, dann habe ich ein bestimmtes Flugportfolio, Reiseportfolio, und wenn ich das dann zugrunde lege, dann stellt sich für mich die Frage: Bei wem bekomme ich denn am ehesten eine Prämie? Und DAS ist eben in der Regel der Carrier, der bei mir vor der Haustür der stärkste ist. Denn wenn jemand anderes für eine Strecke 5.000 Meilen gibt, aber diese Airline tatsächlich nur die eine Strecke anbietet, ich aber ganz viele Strecken brauche und dann ist unter Umständen jemand, der für diese eine Strecke nicht 5.000, sondern nur 500 bietet, aber dafür ein entsprechendes Meilensammelangebot auf ganz, ganz vielen Strecken zur Verfügung steht, dann werde ich diese Airline nehmen. Also es ist tatsächlich so: Es wirkt immer für den Heimatcarrier, für den, der vor Ort besonders stark ist. Dass es dann auch natürlich von den Carriern, abhängig ist, ist ein Meilensammelprogramm jetzt nun attraktiver oder weniger attraktiv, ist sicherlich auch ein Punkt. Wenn ich eben ein eingeschränktes Streckennetz habe, zum Beispiel nur innereuropäisch fliege, dann habe ich schon deutlich weniger Attraktivität in meinem Streckennetz, wenn das dann dort viele Kunden gibt, die dann da auch Intercom-Strecken brauchen und so weiter.

Ein weiterer Punkt ist sicherlich auch das Thema: Um welche Kundengruppe handelt es sich? Denn so richtig spannend ist das Meilensammeln ja vor allen Dingen, wenn ich viel fliege. Heißt ja oft auch Vielfliegerprogramm. Und wer macht das? Das sind in der Regel nicht die Urlauber, sondern das sind die Geschäftsreisenden. Das heißt, da wirkt das besonders gut, wenn die Firma die Kosten trägt für die Reise und der Reisende dann letztendlich davon profitiert. Also die Meilen gesammelt hat und dann irgendwelche Prämien privat nutzen darf. In dem Moment, wo das NICHT der Fall ist, gibt ja eine Reihe von Firmenkunden auch, die gesagt haben: Unsere Mitarbeiter dürfen die Meilen nicht/ dürfen von den gesammelten Meilen nicht selber profitieren. Da ist dann die Wirkung oder die Intensität der Wirkung von Frequent-Flyer-Programmen doch sehr eingeschränkt. Im Privatreisebereich, ja, ich kenne ganz viele, die nur privat reisen, die auch Meilen in irgendeiner Form sammeln, aber ich kenne eigentlich (lachend) keinen, der/ wo das so wahnsinnig große Effekte hat, weil die dann irgendwann auch verfallen. Man macht im Jahr, also selbst, wenn man VIEL, viel Privatreisen unternimmt, in der Regel nicht mehr als, was weiß ich, drei bis vier Trips und die müssen ja dann auch nicht alle mit dem Flugzeug stattfinden. Also das ist schon im Privatreisebereich eher die Ausnahme. Es sei denn, da spreche ich jetzt über so ein Mittelding zwischen Privat- und Geschäftsreisen, diejenigen, die mit dem Flugzeug zur Arbeit fliegen, also so Berufspendler, die irgendwo arbeiten und ganz woanders leben mit ihren Familien, wenn die dann eben eine Woche/ jede Woche einmal hin- und zurückfliegen, dann haben die natürlich ein relativ hohes Reiseaufkommen und dann lohnt sich für die auch ein Meilenprogramm oder die Teilnahme daran, dann können die auch irgendwann davon profitieren, dass sie irgendwie mal einen Freiflug bekommen oder vielleicht mal irgendwie noch einen bestätigten Flug, der eigentlich voll ist oder so. Aber das ist eher die Ausnahme. \#00:11:06-9\#

\section{I: Hm. Gut. Alles klar. Ja/}

Interview 4

Name der Audio-/Videodatei: Interview P4 - Final cut

Dauer der Aufnahme: 00:13:04-9

Datum und Ort der Aufnahme: *durch Interviewer/in auszufüllen*

Besonderheiten: *durch Interviewer/in auszufüllen*

Datum der Transkription: 01.04.20

Ersttranskription: audiotranskription.de Transkriptionsservice

Überarbeitung(en), Datum: *durch Forschende/n auszufüllen*

I: Was ist Ihre derzeitige Position und in welchem Umfang beschäftigen Sie sich mit Kundenbindungsprogrammen in der Airline-Industrie? \#00:00:07-0\# 
B: Also grundsätzlich/ Also Position ist: Ich bin hier an der Universität St. Gallen Titularprofessor und geschäftsführender Direktor des Instituts für Marketing. Das sind ungefähr 30 Leute, die hier beschäftigt sind und unterrichte natürlich auch Marketing. Strategisches Marketing. Unter anderem auch Kundenbindung. Und Kundenbindungsprogramme habe ich bereits auch/ zu Loyalitäts- und Kundenbindungsprogrammen schon seit langer Zeit immer einen Artikel geschrieben, der sich damit beschäftigt hat. Hat sich natürlich stark geändert, also, sage ich jetzt mal, das Thema Kundenbindung so klassisch war ja in den 90ern extrem aktuell. Und jetzt geht es natürlich eher in Richtung Communities und online und, sage ich mal, die meisten dieser klassischen (Cults?) und Clubs lösen sich so ein bisschen auf. Das gilt jetzt nicht unbedingt für die Airline-Industrie. Da ist es ja eher so, dass Winner takes it all, dass die eher so zum Megaprogramm im Laufe der Zeit werden, das heißt, dass die so ein bisschen die Plattform sind für alle anderen, damit man, wenn man kein eigenes Kundenbindungsprogramm betreiben möchte, dass man sich dann da dranhängen kann. Ne? Das machen ja manche auch. Und mit der Airline-Branche, also wir hatten damals mit der Swiss Air noch, als die noch existierte, mit (unv.), da \#00:01:28-6\# immer intensiven Austausch. Ich habe ab und zu Referenten von der Swiss bei mir auch im Unterricht, die die Kundenbindungsprogramme darstellen und habe auch Doktoranden zu dem Thema gehabt. Also nicht spezifisch auf die Airline-Industrie, aber allgemein Kundenbindung, zu dem Thema. \#00:01:43-5\#

I: Hm, alles klar. Vielen Dank. Ja, zweite Frage: Welche Parameter von, ja, Frequent-Flyer-Programmen halten Sie für wirksam oder weniger wirksam, ja, und warum, ja? \#00:01:58-4\#

B: Für mich ist bei den Frequent-Flyer-Programmen eben immer wichtig, also wie bei allen Kundenbindungsprogrammen, auf welches Ziel sie ausgerichtet sind. Das heißt, was man damit tatsächlich bewirken MÖCHTE. Und ganz, ganz wichtig, bei welcher Zielgruppe man das bewirken möchte. Ich unterscheide immer zwei Programme, also dass ich auf der einen Seite sage: Es gibt so manche Kundenbindungsprogramme, das sind die Billig-Kundenbindungsprogramme, die macht man in erster Linie nur, damit man irgendetwas macht, ja? Und das sind dann/ kriegt man eben so ein paar Meilen oder Bonuspunkte, und dann kann man damit nachher irgendetwas machen, weil es einfach marktüblich ist. Und so, dass man sagen kann: Okay, man ist dabei. Aber bei den Frequent-Flyer-Programmen und gerade bei den großen Airlines, glaube ich, ist das ganz klar, dass/ Die Zielgruppe sind ja wirklich die Frequent Flyer oder im Fall von der Star Alliance beziehungsweise der Swiss, da ist es natürlich die (On Circle?) oder zumindest die Senatoren, die man angeht. Und für DIE ist es natürlich das Allerwichtigste nicht, wie viele Pünktchen ich da kriege, wie viele Flüge ich dort kriege, sondern das ALLERALLERWICHTIGSTE ist da die persönlichen Leistungsvorteile, die die bekommen. Also dass sie mit dem Cayenne von Flugbase zu Flugbase geflogen werden, dass der (Mensch in der Kabine?) immer genau weiß, welche Person er vor sich hat, dass er einen begrüßt, dass das Essen dementsprechend auch dann servieren und ausrichten kann, dass die duschen können, dass die eine individuelle Sicherheitskontrolle haben und, und, und. Und das ist EXTREM wichtig. Das ist ja nur für die (On Circle?)-Mitglieder zwar, aber da wirkt das. Also ich kenne auch die ehemalige Leiterin vom (On Circle?) bei der Swiss. Die hat gesagt, wenn sie im September diese Briefchen rauslassen und sagen: Sie brauchen noch so und so viele Meilen, damit Sie nächstes Jahr den (On Circle?)-Status behalten, dann wirkt das dramatisch. Die Leute wollen das behalten. Und diese Zielgruppe, die Frequent Flyer, sind ja auch nicht an Freiflügen mehr interessiert. Das heißt, die wollen ja nicht zusätzliche Flüge machen können. Das heißt, die wollen natürlich Upgrades haben. Das heißt, denen geht es um Convenience, um Bequemlichkeit. Und alles, was, ich sage jetzt mal ganz jovial, was denen hilft, Mister oder Misses Wichtig zu sein, und, sage ich mal, tatsächlich persönlich bedient zu werden, das ist nachher brutal wirksam. \#00:04:26-4\# Aber ich glaube, um die Rabatte geht es nicht. Natürlich hat man das, dieses untere Segment, das ist aber immer wieder reduziert, und dann macht man etwas. Das macht/ Man könnte auch ohne/ Also man braucht die Information der Frequent Flyer Card nicht, also ich weiß zumindest von einigen Airlines, die könnten auch allein mit Data Mining zuordnen: Welcher Passagier ist geflogen, ohne dass man die Frequent Flyer-Nummer eingegeben hat. Das wäre technisch überhaupt kein Problem. Ob man es darf, ist eine andere (lachend) Sache. Aber man könnte das theoretisch. Das heißt, Zusatzinformationen, das darüber zu kriegen, darum geht es eigentlich gar nicht, sondern es geht in erster Linie tatsächlich um das Segment der Vielflieger, der richtigen Vielflieger. \#00:05:07-5\#

I: Hm. Ja, vielen Dank. Wie würden Sie Frequent-Flyer-Programme weiterentwickeln, damit die effektiver werden und was würden Sie hoffen zu erreichen? \#00:05:16-9\# 
B: Ja, also ich finde, sie machen es sehr gut. Ich würde es tatsächlich auf diese Zielgruppe weiter ausrichten, dass man denen tatsächlich einen Vorteil bietet. Ich glaube auch, bei Kundenbindungsprogrammen ist es tatsächlich so: Winner takes it all. Die Leute wollen nicht in 20, 30, 40 verschiedenen Kundenbindungsprogrammen sein, sondern sie wollen gerne in einem haben und fokussieren dann alles dadrauf. Das heißt, in der Schweiz merkt man das zum Beispiel sehr stark, dass dann die Leute auch versuchen, ihre Kreditkarte auf Miles and More umzustellen statt auf die klassische Hausbank einfach, dass man in einem System ist. Und weil, wenn man in einem System ist, dann kriegt man auch alles in diesem gutgeschrieben und das ist dann natürlich ein Vorteil. Alles, was zum Thema Convenience, alles, was zum Thema what money can't buy, würde ich sagen, (macht?). \#00:06:16-3\# In die Richtung würde ich es für das Segment weiterentwickeln. Für das andere Segment glaube ich gar nicht mal so, dass es so stark wirkend ist. Also weil da ist tatsächlich das aktuelle Preis-Leistungsverhältnis, da ist die Transaktion viel, viel wichtiger, im preissensitiven Bereich. Also ich glaube NICHT, dass da die Kundenbindungsprogramme einen Rieseneffekt auf das Buchungsverhalten haben werden. Sondern da ist es viel, viel wichtiger, wie das aktuelle Preis-Leistungsverhältnis ist und da kann man vielleicht eine Analogie zu Dell ziehen, die schon immer gesagt haben: Okay, wenn Sie Business to Consumer haben, dann versuchen Sie keine Geschäftsbeziehung zu haben, sondern da versuchen Sie die beste Transaktion zu gewährleisten. Und im Business to Business, wenn Sie gegenüber Firmen ein Geschäft machen, dann versuchen Sie so richtig Geschäftsbeziehung aufzubauen. Und hier ist es aus meiner Sicht auch so. Airlines müssen im preissensitiven Bereich das beste Preis-Leistungsverhältnis bieten. Da, glaube ich NICHT, dass die Frequent-Flyer-Programme, sage ich mal, sehr, sehr stark wirken. Man muss etwas haben, weil alle anderen auch was haben, dass man einfach sagen kann, man macht mit, dann kann man so ein Billigprogramm in irgendeiner Form machen, aber für die Oberen, geht es tatsächlich um das Thema Convenience und persönliche Betreuung. \#00:07:32-1\#

I: Hm. Alles klar. Vielen Dank. So. Sind Sie der Meinung, dass die Wirksamkeit von Frequent-Flyer-Programmen darüber hinaus von weiteren Parametern abhängt oder ist das im Prinzip schon durch die Frage 3 hatten wir das jetzt schon (unv.)? \#00:07:48-6\#

B: Von welchen weiteren/ Also pff/ Also das müssen Sie natürlich immer optimieren. Also es geht jetzt um strategische oder operative Optimierung, also operative Optimierung wäre solche Fragen: Wie verfallen die Meilen und also etwas da/ Das kann ich jetzt eh nicht beurteilen. Ich glaube, für das oberste Segment dürfen sie nicht verfallen. Beispielsweise da gibt es ja nur Diskussionen und solche Diskussionen will man ja überhaupt nicht haben mit dieser Zielgruppe, ob da jetzt Meilen verfallen. Das sind eher andere Effekte. Es gibt natürlich schon/ Also WICHTIG ist natürlich schon das Thema Kooperation. Das heißt, die Star Alliance ist nun mal der größte Player und die ganze Alliance One World oder so, dann/ Das sind natürlich wichtige Allianzen. Aber das spielt natürlich schon eine Rolle für das Programm. Aber was uns/ Natürlich ist es schön, wenn man das erweitern kann, diesen Service, beispielsweise auf alles, was reisenah ist. Also wenn man tatsächlich so ein (seemless?) Customer Journey machen könnte, die auch das ganze Thema Hotels und Mietwagen und so etwas mit abdecken würden. Andererseits bin ich der Meinung, dass das so gerade im B2B-Geschäft so schwierig ist, weil die meisten Unternehmen da natürlich ihre eigenen Regularien haben, genau festgelegt, in welchen Hotels die absteigen dürfen, welche Mietwagen die nehmen und die haben da schon allgemeine Rahmenverträge. Da wird die Komplexität einfach extrem hoch und ich weiß nicht, ob dann der Nutzen tatsächlich die Kosten übersteigt. Also da kann ich jetzt wenig sagen, also da weiß ich jetzt nicht, was da noch an Parametern kommt. \#00:09:51-3\#

I: Okay. Vielen Dank. Und da kommen wir schon zur letzten Frage: Glauben Sie, dass die Wirksamkeit von Frequent-Flyer-Programmen je nach Kundentyp, Reiseart und Fluggesellschaft unterschiedlich ist? Wenn ja, in welcher Hinsicht? \#00:10:04-4\#

B: Ja, also Kundentyp habe ich ja schon gesagt. Also das heißt, für die richtigen Frequent Flyers und eventuell auch noch für die Senatoren, also für (On Circle?) und Senatoren, mit Sicherheit wirksam. Da. Reiseart: Pff. Ja, man kriegt die ja nach wie vor privat eigentlich, obwohl das bei vielen Firmen nicht erlaubt ist. Ne? Also das ist natürlich etwas, was bei Punkt 4 noch mit reinkommt, ne, das, was die Regulierung/ Wie sind die? Darf ich solche Rabatte annehmen? Ist das noch compliant? Das hat eine große Auswirkung, weil viele Topmanager natürlich, wenn das nicht mehr compliant wäre, das zu machen, allein aus Sicherheitsgründen das dann nicht 
mehr machen würden. Das heißt, Compliance ist schon ein wichtiges Thema, die es gibt.

Reiseart: Also für Businessflüge wesentlich wichtiger.

Fluggesellschaft: Ja, hat einen Einfluss. Natürlich bei den Low Cost Carriern ist es weniger wichtig, da muss ich eben so ein Billigprogramm dort haben ODER ich habe dort so ein Programm, das ist dann für die besten Kunden $\mathrm{im} /$ bei denen, die auch preissensitiv sind und Low Cost Carrier fliegen, aber trotzdem das Businesstraveln gewohnt sind. Dass ich da mehr oder weniger so einen Ausgleich mache, dass man mehr oder weniger den gleichen Service bekomme, wie ich ihn sonst bei klassischen Airlines bekomme. Aber eigentlich hängt das mehr mit der Buchungsklasse zusammen, also wenn ich Business buche, dann habe ich ja das und das kann ich da manchmal nicht, also deswegen. Ja, da wird es sich ein bisschen unterschieden.

Ich glaube, es hat auch noch einen Einfluss bezüglich der Länder. Also ich weiß, dass die Schweizer, die Holländer und die Südafrikaner sind einfach sammelwütig und andere Länder, die Franzosen, sind nicht ganz so sammelwütig. Das heißt, das hat mit Konsumentenverhalten zu tun. Das zeigt dann auch die Wirksamkeit von vielen Kundenbindungsprogrammen, gerade, wenn man so sammeln muss. Das funktioniert nicht in allen Ländern gleich und das ist natürlich dann auch von einer Landesgesellschaft, also (Landesfluggesellschaft?) abhängig. In der Schweiz wird natürlich die Swiss, obwohl sie ja eigentlich deutsch ist, aber hat einen extrem guten Ruf, auch Schweizerischen Ruf intern und wenn man natürlich nicht so eine dominierende Landesairline hat, dann wird natürlich/ Dann ist automatisch das Frequent-Flyer-Programm auch weniger nützlich. Weil wenn ich fliege und verteile mein Wallet sowieso auf zehn verschiedene Airlines, dann kann ich nachher sowieso nicht in allen Airlines was erreichen, wenn ich natürlich in einem Land bin, wo fast alles dann mit einer Airline ist, dann ist das wesentlich einfacher, dort alles zu machen. \#00:12:58-3\#

I: Hm. Ja, herzlichen Dank. Dann wären wir mit den Fragen und dem Interview auch schon durch. Interview 5

Name der Audio-/Videodatei: Interview P5 - Final cut

Dauer der Aufnahme: 00:16:54-3

Datum und Ort der Aufnahme: *durch Interviewer/in auszufüllen*

Besonderheiten: *durch Interviewer/in auszufüllen*

Datum der Transkription: 01.04.20

Ersttranskription: audiotranskription.de Transkriptionsservice

Überarbeitung(en), Datum: *durch Forschende/n auszufüllen*

I: Erste Frage: Was ist Ihre derzeitige Position und in welchem Umfang beschäftigen Sie sich mit Kundenbindungsprogrammen in der Airline-Industrie? \#00:00:09-3\#

B: Ich bin Leiter des Luftfahrtkompetenzzentrums der Uni St. Gallen und beschäftige mich mit Loyalität/ Also sozusagen habe ich mich im Moment nicht gerade direkt, aber in der Vergangenheit mit Kundenloyalitätsprogrammen beschäftigt. Sie sind immer interessant. Auch immer die Frage, ob sie denn wirklich diesen Benefit auch wirklich bringen, den sie sollten. Und da gibt es ja unterschiedliche Meinungen und ich sage mal so, ich habe mich mehr dann eher wissenschaftlich oder auch über Diplomarbeiten, die ich betreut hatte, damit beschäftigt. \#00:00:51-2\#

I: Hm. Vielen Dank. Welche Parameter von Frequent-Flyer-Programmen halten Sie für wirksam oder weniger wirksam und warum? \#00:01:00-9\#

B: (...) Also erstens, wir reden von Frequent-Flyer-Programs, zum Beispiel wie Miles and More oder so. 
\#00:01:09-0\#

I: Ja, ganz genau. \#00:01:10-4\#

B: Das heißt die Kundenprogramme. Es geht um die Kundenseite und nicht um die Airline-Seite. Ist das richtig? \#00:01:14-2\#

I: Das ist richtig, genau. \#00:01:15-7\#

B: Genau. Also im Prinzip sehen wir diese Punkte, die man da sammeln kann, die sammelt man ja mittlerweile nicht nur mit Fliegen, sondern auch, wenn man die Kreditkarte nutzt oder so, also wenn ich die Kreditkarte nutze, kriege ich pro Franken, den ich da ausgebe, eine Meile und habe mal dann irgendwie drei-, vier-, fünfhunderttausend Meilen oder mehr auf dem Account, also man hat plötzlich eine Meilenflut und von dem her ist ja eigentlich gar nicht mehr nur Flugmeilen, sondern es sind ja eigentlich wie so Punkte, die man bekommt. Auch beim Supermarkt oder so gibt es ja bei uns in der Schweiz bei der (Mikro oder beim Koop?) gibt es ja auch diese Sammelpunkte und dann kann man dann wieder/ bekommt man Gutscheine und so weiter als Gegenleistung. Und ich sehe das eigentlich ein bisschen so: Der Vorteil ist, man sammelt Punkte und man kann die Punkte eigentlich wie Bargeld einlösen. Also ich kann dann zum Beispiel habe ich mir kürzlich einen Koffer gekauft mit Meilen. Einmal habe ich mir die Armbanduhr gekauft mit Meilen. Also man kann sich jetzt also die Meilen einsetzen, wie man will, das ist so quasi wie ein Dankeschön für das loyale Fliegen. Aber eben nicht nur für das loyale Fliegen, sondern man kriegt ja eben auch, wenn man eine Swiss-Kreditkarte hat, dann bekommt man ja Meilen auch für jeden Franken, den man ausgibt. Und so, ja, hat man eigentlich/ kann man diese Meilen dann einsetzen. Und was ich am besten finde, wir haben auch Studien dazu gemacht, wo bekomm ich am meisten für meine Meilen. Am meisten bekomme ich, wenn ich sie verfliege. Also die Airline gibt mir eigentlich am MEISTEN für die Meile, wenn ich Flüge buche oder upgrade. Also jetzt zwei, drei Jahre her, seid wir die Studie gemacht, da bekommt man am MEISTEN fürs Geld, wenn man das umrechnet, man kann ja dann diese Flugmeilen in einen Finanzwert umrechnen und könnte sagen: \#00:02:57-1\# Okay, die Uhr kostet irgendwie 500 Franken und ich muss hierfür 100.000 Meilen geben, also 100.000 Meilen sind dann irgendwie 500 Franken oder eben so. Und so kann man über das ganze Produktportfolio hinweg kann man dann diese Durchschnittswerte finanziell ausrechnen und kommt dann zu einem Durchschnittswert, was so eine Meile wert ist. Und dieser Durchschnittswert, wenn man vergleicht, man bekommt für eine Meile, die man fliegt oder upgraded, ist das höher, wie wenn man Produkte kauft. Das haben wir mal festgestellt. Und das Fliegen ist ja aber eben gerade das Problem, weil das kann man ja praktisch nicht, weil immer, wenn man ja fliegen WILL, dann gibt es einfach keinen Sitz. Das ist ja auch ein bisschen das Thema, oder? Man möchte ja dann mal/ Ich habe schon x-fach versucht, meinen Meilenflug einzulösen, einfach auch geschäftlich, um mal diese Meilen wieder abzubauen und so weiter, oder, und dann sagt es, wenn ich da/ Mein Flug geht dann meistens nicht, das heißt, man bekommt dann irgendwelche Flüge von Zürich über Düsseldorf nach Kopenhagen oder irgendsowas Verrücktes, oder, und das will ja keiner. Man will ja einen Direktflug haben. Und dann bekommt man dann ganz komische Angebote. Upgrades gehen. Die gehen manchmal auf der Langstrecke, wenn es Platz hat, kann man ein Upgrade machen oder so, das ist mir auch schon gelungen, das geht. Wo man sie immer einsetzen kann, indem man einfach Produkte kauft, also indem man wirklich auf den Onlineshop von zum Beispiel Miles and More geht und dann halt wirklich Koffer, Uhr, was auch immer, Computer, da gibt es wieder (unv.) \#00:04:20-1\#, da kann man ja alles kaufen, damit/ Also eigentlich ist es wie eine Währung, könnte man sagen. Und da gab es ja dann auch diese Studie, da gibt es auch ein Projekt dazu, wo einer gesagt hat: Eigentlich möchte man die Meilen und gerade (Störung in Aufnahme) \#00:04:33-1\# umwandeln, dass man sie eigentlich so wie eine virtuelle Währung benutzen kann. Und eigentlich über eine Karte auch damit zahlen kann, zum Beispiel dass man die zum Beispiel auf eine Kreditkarte draufgibt oder irgendsowas. Da gibt es ja ganz verrückte Ideen. Nur wenn man das so macht, dann ist es ja keine/ Also dann ist das ja nicht mehr/\#00:04:54-5\#

Abbruch in Datei \#00:04:55-5\#

B: Hallo? \#00:04:56-4\# 
I: Ja, Mark (Weefer?), hallo. Ja, das tut mir leid, da ist auf einmal die Leitung zusammengebrochen. Ich habe es jetzt nochmal über eine andere Leitung versucht. Tut mir leid. \#00:05:04-4\#

B: Okay, okay. \#00:05:06-1\#

I: Ja. \#00:05:06-8\#

B: Ja, ja. Hoffen wir, dass es klappt. \#00:05:09-7\#

I: Ja, ja. Nein, denke/ Denke, jetzt klappt es. (lacht) \#00:05:12-1\#

B: Aber haben Sie alles gehört, was ich gesagt habe? \#00:05:14-8\#

I: Ja, ich habe dann/ Genau. Ich habe bei der Frage zwei ja praktisch, dass es dann wie eine digitale Währung ist, bis dahin habe ich im Prinzip noch alles mitbekommen, genau. \#00:05:26-2\#

B: Ja, genau. Also eben genau, das ist ja eigentlich dann wie eine, genau, digitale Währung. Und die Frage stellt sich ja dann, ob so eine Währung, ob das wirklich dann Loyalitätsmechanismen auslöst oder nicht, oder? Früher war es ja eigentlich so, man hat Meilen gesammelt, um dann Flüge zu buchen oder Upgrades zu bekommen und hat das eigentlich mehr Flug/ also im Flugbusiness, also mit der Airline selbst, dann irgendwo wieder eingelöst und es war so wie so ein/ ja, ein Kickback für gute Kunden. Und heute ist/ Also ja, und den man sich selber/ Quasi/ Man hat ihnen quasi Naturalien geschenkt, zum Beispiel einen Flug, könnte man sagen. Das ist ja dann ein eigenes Produkt. Und heute ist es so, dass es wie eine Geldwährung geworden ist und damit natürlich kommen auch ganz neue Fragen der Versteuerung von Einkommen auf zum Beispiel. Dass man sagt: Ja, Moment mal, wenn man da Geld gibt, dann muss es ja als Einkommen versteuert werden, dann ist es eben steuerbar und so weiter und da gibt es die ganzen Diskussionen, wo dann natürlich der Markt kommt: Ja, dann verzichte ich lieber auf meine Meilen, wenn ich da noch Steuern zahlen muss dafür, weil ich zahle schon genug. Oder? Da gibt es dann so die ganzen Mechanismen in der Diskussion dazu. Aber (unv.) \#00:06:39-8\# so bisschen das Thema, die Airlines selber sind ja selber auch nicht begeistert von der Entwicklung von diesen Meilen, also die Entwicklung und die Wahrnehmung dieser Flugmeilen führt eben dazu/ Ja, führt nicht/ Also aus Sicht der Airlines, also wie ich es oft gehört habe, führt zu wenig zu Loyalität und eben Wiederkauf und diese Bindung, die nimmt tendenziell/ Die Stärke der Bindung über diese Meilen, die nimmt ab mit vielleicht auch zunehmend dynamischeren Preisen und tieferen Preisen und Transparenz über alle Airlines hinweg zum Schluss. Aber das/ Da gibt es/ Das ist ja wie/ Die Meilen, also diese ganzen/ Die Loyalität dahinter, die wird immer mehr in Frage gestellt in der Industrie. \#00:07:34-4\#

I: Hm. Okay. Und wie würden Sie Frequent-Flyer-Programme weiterentwickeln, damit sie effektiver werden und was würden Sie hoffen zu erreichen? \#00:07:43-8\#

B: Ja, für mich ist ein Frequent-Flyer-Programm halt immer noch ein Loyalitäts-, ein Bindungsprogramm, ein Kundenbindungsprogramm, und aus der Perspektive der Airline oder (unv.) \#00:07:56-9\# viele vergessen, ist das noch ein Wert. Einer der wenigen Werte, die eine Airline überhaupt noch hat. Also ich meine, sind wir ehrlich: Eine Airline ist ein Commodity-Produkt. Sind alle genau gleich. Sind die gleichen Flugzeuge, gleichen Sitze, sie sind alle mittlerweile nicht mehr gut in/ Ich meine, es ist überall eng und unangenehm in der Economy Class, in der Business Class differenziert man noch ein bisschen. Aber ich sage mal so: Der Unterschied der Produkte ist ja nicht mehr wahnsinnig groß. Und damit ist das Switching-Verhalten der Kunden sehr groß geworden. Man schaut sich halt Schluss wirklich nur noch den Preis an, weil alles andere ist eh wurscht, es ist ja eh überall das Gleiche. Oder? Und das ist dieser/ Dieser Trend führt natürlich dazu, dass gerade dann eben so Loyalitätsprogramme vielleicht wieder relevanter werden und vielleicht noch einer der wenigsten USPs oder, sagen wir mal, einer der wenigen Value-Treiber sind, die ein Unternehmen noch hat strategisch. Ich meine, im 
Pricing, über dynamische Preise, kann man sich nicht mehr differenzieren. Das machen alle perfekt, haben alle in der Industrie perfektioniert. Über Netzökonomie und Netzeffekte und optimale Netzentwicklung kann man sich auch nicht mehr profilieren. Das machen auch alle bis zur Perfektion. Da stellt sich die Frage: Wo kann man sich dann überhaupt noch abgrenzen und strategisch entwickeln? Und da sind dann gewisse Ressourcen natürlich relevant, zum Beispiel Innovationsfähigeit, eine Marke, eine starke Marke irgendwie, die positioniert ist, eben Loyalität, Kunden- und Loyalitätsprogramme. Kunden, die eben, ja, die irgendwo/ die man halten kann. Und ich glaube, darum sind diese Programme/ sind die schon wichtig, auch wenn sie nicht mehr so wichtig angenommen werden. Jetzt habe ich aber Ihre letzte Frage nicht ganz massiv beantwortet, glaube ich. Jetzt habe ich ausgeholt. Können Sie die nochmal sagen? \#00:09:48-4\#

I: Ja. Wie würden Sie die Frequent-Flyer-Programme weiterentwickeln, damit sie effektiver werden und was würden Sie hoffen zu erreichen? \#00:09:56-1\#

B: (...) Ich glaube, Frequent-Flyer-Programme müssten einerseits/ Also es gibt zwei Wege. Den einen Weg ist wirklich die Kreditkarte, also man schreibt die Meilen quasi mit diesen Schweizer Franken auf der Kreditkarte gut und hört auf mit dem ganzen Drum und Dran da mit den Meilen. Da würde ich mir vorstellen, dass das vielleicht zu wenig Loyalität oder zu wenig Wahrnehmung von Loyalität führt. Darum gefällt mir die zweite Variante besser und die ist wieder verrückt und (unv.)-Geschäft. \#00:10:28-6\# Mit Flugmeilen bekommt man Flüge. Mit Flugmeilen kann man am Flughafen essen gehen, mit Flugmeilen kann man eine Priorität haben bei einer Security Line, mit Flugmeilen kann man beim Check-in beim Business Class-Einchecken statt bei der Economy, wenn man so viele Flugmeilen hat oder so. Mit Flugmeilen kann man irgendwo im ganzen Flugprozess sich einen Vorteil holen. Und ein Vorteil heute im Flugprozess hat mit Zeit zu tun. Es möchte niemand anstehen, es möchten alle die Priority Line haben, es möchten alle noch den Kaffee trinken gehen noch kurz am Flughafen, wenn man Zeit hat. Also das wären alles Möglichkeiten im Flug, im ganzen Reiseprozess drin, den Passagieren eigentlich Möglichkeiten zu geben, Lounge Access. Ich kann mir Lounge Access kaufen mit Meilen, ich kann mir einen Kaffee kaufen in der Cafeteria, ich kann bei der Priority Line durch bei der Security, ich kann bei der Priority Line einchecken. Ich weiß nicht, aber ich habe irgendwo am Flugprozess bezogene Vorteile. Ich kann einen Upgrade buchen, ich kann einen Flug buchen und ich bekomme auch einen Direktflug, wenn ich will. Der kostet halt vielleicht dann mehr wie ein Umsteigeflug, aber ich kann ihn auch buchen und mit den Meilen bezahlen. Nicht so wie heute, wo man ja nur noch die Flüge bekommt, die man nicht will, wenn man mal einen mit Meilen buchen will. Ich glaube, ICH würde sagen, WENN dann zurück zum Fluggeschäft, zum Prozess von zu Hause bis zum Ziel zurück nach Hause. Das kann ein Limousinenservice sein, der einen ins Hotel bringt. Oder in der Business Class bei Emirates Airlines bekommt man das. Da kommt die schwarze Limousine, fährt einen ins Hotel, holt einen wieder ab, das ist da dabei. Jetzt könnte man sagen: Ja, wenn ich viele Meilen habe und Economy Class fliegen muss, weil gerade eine schlechte Wirtschaftslage ist und ich kann geschäftlich auch nicht in der Business, dann kann ich meine Meilen nehmen, um dann eben diesen Limousinenservice vielleicht trotzdem zu haben oder irgendso. \#00:12:20-4\#

I: Hm, okay, vielen Dank. \#00:12:22-0\#

B: Also ich würde wirklich Flugprozess, Loyalität, wirklich dann die Leute am Flugprozess behalten. $\# 00: 12: 27-4 \#$

I: Hm. Okay. Dann vierte Frage: Sind Sie der Meinung, dass die Wirksamkeit von Frequent-Flyer-Programme von weiteren Parametern abhängt? \#00:12:38-9\#

B: (...) Ja, es kommt natürlich immer drauf an auch noch: Wie groß ist dann eben das Netzwerk? Also wenn ich jetzt eine Star Allianz habe und ich sammle Flyermeilen bei/ Ja, habe ich ein Lufthansa-Modell oder so und (wie?) bei Miles and More dann kann ich ja die in der ganzen Allianz mit den Partnern kann man ja Vorteile dann haben oder es ist ja dann so, dass man, je größer das Netzwerk ist, desto größer ist auch der Pool, wo ich sammeln kann. Also auch, wenn ich jetzt Singapur Airlines fliege, da sammle ich bei Miles and More und so weiter, aber das ist natürlich ein Faktor, der zentral ist. Also die Größe eines Gesamtnetzes, wo diese Programme 
dann quasi Partnerschaften haben. Die ist natürlich oder einerseits. Auf der anderen Seite heißt das wiederum, das ist der negative Effekt dann wieder, der Countereffekt, ja, mit je mehr Airlines wir Vorteile wir geben für EIN Meilenprogramm, desto weniger Loyalität mit einer einzigen Airline muss ich haben. Das heißt, ich schaffe mehr Loyalität mit Allianzen, auf Allianz-Ebene, und weniger auf individueller Airline-Ebene. Und ich glaube, das muss auch wahrscheinlich das Ziel sein, dass man versucht, die Leute ins Allianz-Netzwerk reinzuholen und DANN durch die Anbindungen, die man dann hat im Allianz-Netzwerk, also wenn man da mal drin ist, die Leute im Allianz-Netzwerk zu behalten, so profitieren alle Partner vom globalen Kunden, die dann irgendwo global unterwegs sind. Wogegen, wenn ich es auf die Einzelairline beziehe, dann habe ich ja ein viel kleineres Netzwerk und bin nur auf einem Markt tätig. Also nur auf einem Markt dann vielleicht Loyalitätseffekte. \#00:14:31-3\#

I: Hm. Okay. Und die letzte Frage: Glauben Sie, dass die Wirksamkeit von Frequent-Flyer-Programmen je nach Kundentyp, Reiseart und Fluggesellschaft unterschiedlich ist? Wenn ja, in welcher Hinsicht? \#00:14:45-5\#

B: (unv.), diese Flugmeilen bringen ja nur denen etwas, die auch viel fliegen. Oder? Das ist ja auch die Idee der Loyalität. Also wenn ich jetzt zum Beispiel ein Kunde bin, der einmal im Jahr in den Urlaub fliegt in Europa irgendwo nach Mallorca oder so im Sommer immer nach Spanien mit der Familie und wieder zurück, dann bringt das alles nichts, das ist nicht/ Aber das ist ja dann eben auch nicht/ Da soll es ja auch nichts bringen, weil das hat ja nichts mit Loyalität/ Loyalität sind dann ja immer die Vielflieger, die guten Kunden, die man belohnen will. Man könnte aber auch argumentieren, dass man sagt: Okay, ich bin (unv.) Air, das ist da \#00:15:19-8\# dieser Ferien Carrier von der Swiss Lufthansa, die nach Zürich fliegt und ich möchte, dass die Kunden immer mit uns buchen und nicht mit unserer Konkurrenz EasyJet oder so. Oder? Und da könnte man doch schon auch argumentieren, man möchte die binden. Vor allem eben die haben keinen Vorteil durch diese Meilen, weil die kommen nie auf ein Level, dass sie die Meilen überhaupt irgendwie einsetzen können. Das heißt, da stellt sich dann die Frage: Sind Meilenprogramme eigentlich die richtigen Loyalitätsprogramme? Oder sollte man gar nicht Meilen machen? Sind es, ich weiß nicht, pro Betrag, den man bezahlt oder so Kaffeegutscheine für die Cafeteria im Flughafen oder ich weiß es nicht oder vielleicht gibt es da ganz andere Grundlagen, aber nicht die Meilenpunkte, die man dann divers einsetzen kann. Da haben wir auch mal eine Diplomarbeit gehabt, (da wurde?) diskutiert, wie man (freiwillig?) das ideale Programm haben, machen könnte, das eben gerade dem Leisure-Kunden/ dass quasi den Leisure-Kunden dazu bringt, auch im nächsten Jahr wieder mit der gleichen Airline zu fliegen. Der fliegt nur einmal im Jahr, aber möchte auch den halten. Auch den (nächsten?) (unv.). \#00:16:32-3\# Was muss man dem geben, dass er nicht plötzlich Ryanair oder EasyJet fliegt, weil die kämpfen natürlich (unv.) brutal über den Preis. Da sind es nicht Meilenpunkte, da muss es etwas anderes sein. \#00:16:47-2\#

I: Hm. Ja gut, vielen Dank, das waren die fünf Fragen, die ich/

\section{Copyrights}

Copyright for this article is retained by the author(s), with first publication rights granted to the journal.

This is an open-access article distributed under the terms and conditions of the Creative Commons Attribution license (http://creativecommons.org/licenses/by/4.0/). 